る。柷世代 旦

かはにに一

歺祖連㺼

が先する 題

ら崇家先公

現を崇 在

在家統拝

は同に究

産族機は

羍化社熋同

近會儀祭

代造礼 。

华造と各

社脈て の

会絡扱先

変考て 祖

動察き

关した帚た者

家もこ族

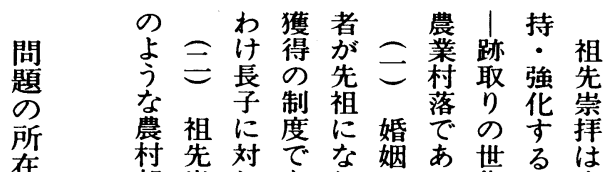

部崇しあれのる代機直

で择こつな絵山間能系

行ののたい馬形のを蒙

な祭儀地と習県構果族

わ儀礼域 い俗村造守に

れのをにうに山的。お

る実行おの認郡結本け

現施ついはめ黒合稿る

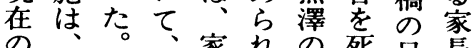

祖生 天家れた允者貝長

先業逝創家力供は跡

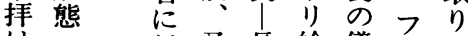

は: 対又長絵儀オの

家家すは子馬礼 1 権

々族る継の䏨の威

密類婚承多俗中主

接型姻さイとに方義

ので分。

増 あ析超

な家 儀せ户祖確に的

関家 礼る\%先認よな

係格はなド崇すす亩

維家家のは择る提䍏

家
祖
先
崇
洋
山
形
県
睪
事
列
中
心
に

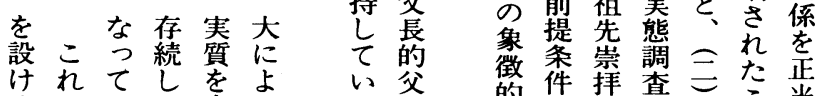

持父前祖泰と唣委

るにいて失りる父的件择查巨こ当

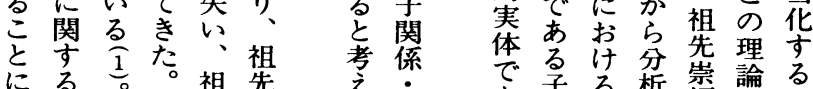

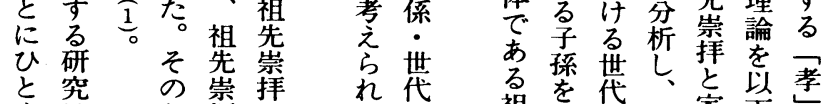

ま㤬た洋の

成現 現基

功在 最代と

乙変望家な

い動はの家

るの祖 変.

と指 先化同

言標容に族

て例合 か

よ学譱せた

れ帒る秄世䒫掏点孝

る。深 祖残閏次家市寺

の にな関結構三儀

家占方主論連点礼

の家をた主を得関関し

構妿か客た测しを

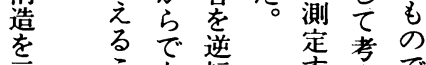

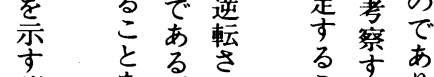

諸 をる。さ る るす す

変意婚た と、气家

。位莒そ方

し牌主の !

か牌王機 シ

ᄂ, 蓦 な 能 $\exists$

位承閴を変と

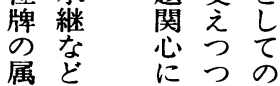

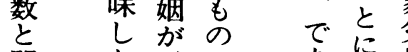

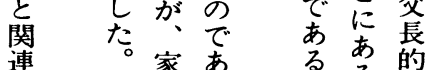

連家格る る。る家義

持長維る。こ二族

櫻

井

っは持末婚問こ合 


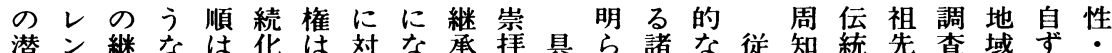

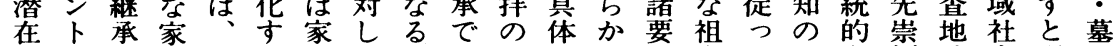
的なに長跡る長二。な連的に因先て通な看域会限の な関関と取この切そさ関にし、崇、り祖がに界設 対係守跡りと権のしれを拝本で先設お構が定

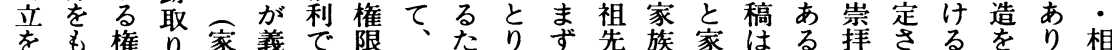

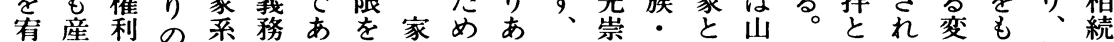
和み.-関継でり、有長にげ伝遅地の形い容視祭条 寸出義係承も、しの統の域連県门現前野跑件 るし務傃あ前、地家い蒙変の関南理在のにをか のたのは、つ家先位長。族容社を村念の祖収行ら で。関親のた系祖はと家に拿探山型も先めなの あ至係䅐家。継の家跡でお論構り郡 る。高で関長ま承感を取は情草造次黑 しつつ係対老を現の系家予関にの

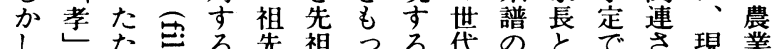
なとあ总巷崇とてるの間超跡あ゙せ 現業 がしに怘順据し統で関世垈㷅るた構祖落 の心て必おそし家が的の造先対 家祖理で要け的あ求る権た長忠関帒 々崇にる粚前威。家的が閶 跡帱予以る蒙を祖産な家関 取はン上。長復先・家長係 ク两ビにこ命位の家族の地 は世本代ヶ地よ恭永祭盛結地祖

- 崇 象

機洋に 能 を

論 規 過

の 定去 章至 場で伝

\section{にの崇るう み}

関と帱必家先 し 対 が要族 祖 て比明富 の 観 も过 ら 末てに。ら先 解いさまず崇 決るれた、择 の場な々 の 問合い変れ機 題がま容が能 が少まを組を 多な、論み探 いく理じ込る こな念るまこ とい的際れと

が減業る。連力生さ子照構せ先逆に逆さ华持たを啠 範てのかに明リる或玄化強。はるのてれえ息つに 意い進つ、ら絵こ特いるさ化逆つ供、なな子て互 識る展て現か馬と別はきれ禁縁孝子養本もいとく恵 に。に農代に習もに養とたるのてがに研の。てれ関 あしょ村のし俗あ育子も社た観の親焦究で祖父る係 クかり家農たをつてに可会め念対よ点であ先親跡に

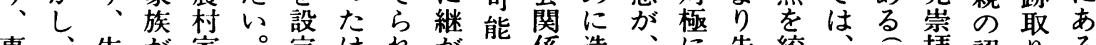
事、生が家。定はれが熊係造、に先絞、家搳認りる

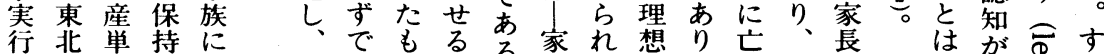

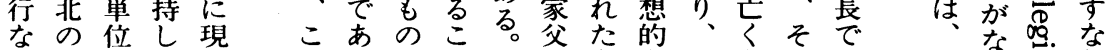
わ農が存 のるのとも長もなそなこは た志わ

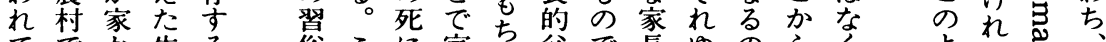

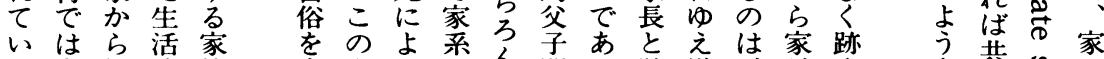

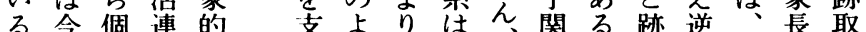
。な人関性之方連跡係な取縁最とり

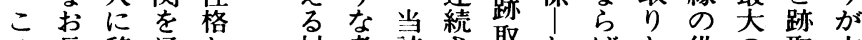
の長移通と村考該さ取とばと供の取亡 よ男行 し 祖 广跡て の 伝取い高据 統りるいの 的已凝 関 三 $の$ 集連 世単に性を 代独よは考 家相続 低兼察 落察篮れり観市養不り 構ののるが念逆関は孝のな 造対零が死体に係祖と関う 家象落、家だ系周順先言係た の後い系場祖辺縁择れ考合 構にし継合先の|にる察 造述は承で崇考を対よ㥹す と䇼を毛择察際置うるす

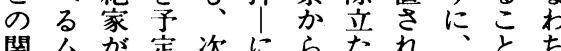
な共告の 世茼导 の 代 体奏 関成兄と 関員に先 㑊権はこ

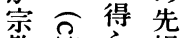
教名 ら 祖 的突れの 世』な地 界气 に节しは 儀をま自 
家が主商る
あ農責

り、婪旅落山

大経 桃館落 形

半棠葡業あ盆

が耕萄工る。地

兼地面星骛南

羍面果樹乍落西

乙禁な総隅

心る培气数山

る。水残面市

年体稲り塄の

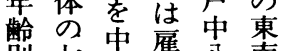

別七心角八南

の割心者置方

農弱し煮芦が五

就一た帯農キ

労人農で家口

者ク業あでメ

数多営る。他卜

はル専はル

男末れ業自に

女満て農営位

と農る家声置

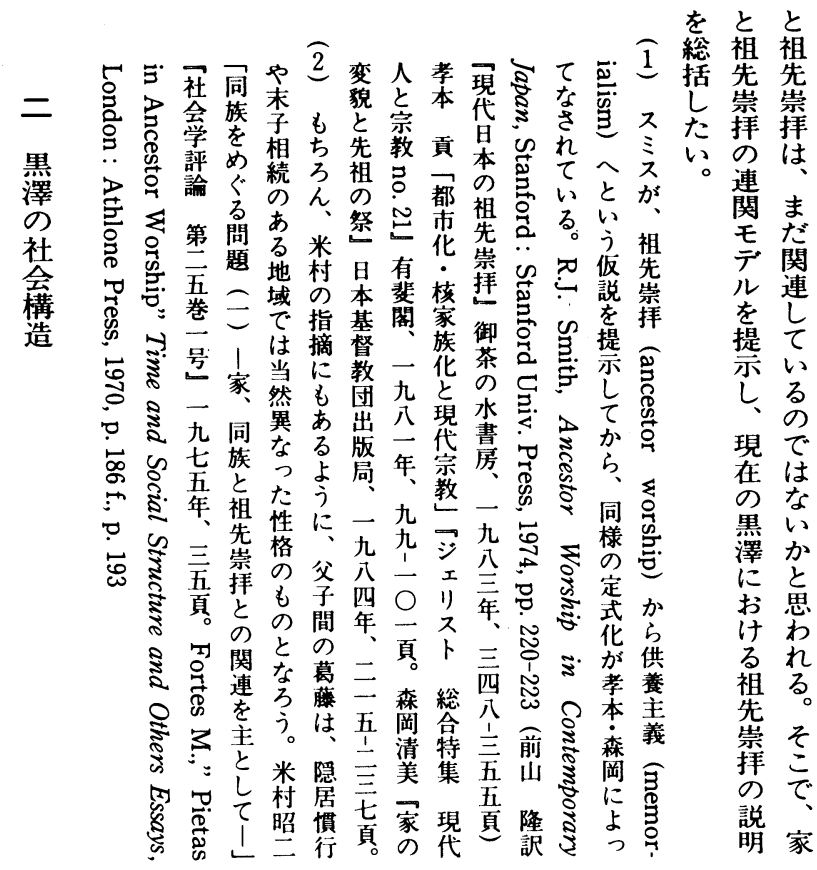

とはうい方四みに治て主に関株!は全の打领は五 本年村た少に九四い花か係を名一般領帳歴と十 家マコ山。作町、九四たしけで持子、に主交史い藏 がキ1。地まに照町年。たてはたの去わ最に上う以

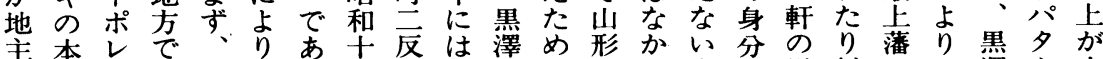

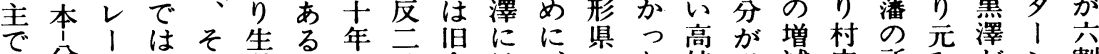

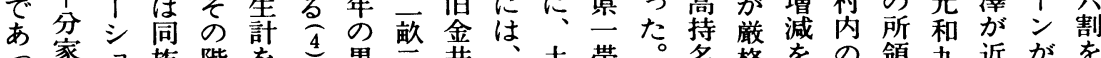
つ冢 $\exists$ 族階を黑三并要带。名格をの領九近がを

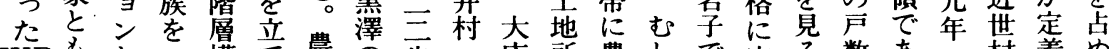
WBもと名構て農の歩へ庄所農しで守る数あ乞村着め

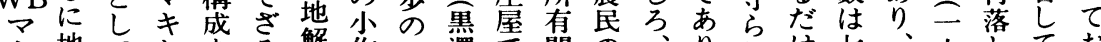
キ地てとをる解作田澤で関の、りれけ七、六とてお の主のい同を放地地・金係階黒焦で士羽三しいり

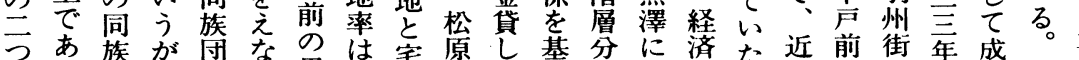
でっ族か、団な黒宅原基分に済た近前街年成。専

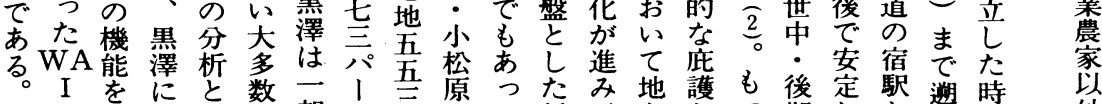

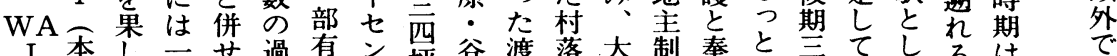

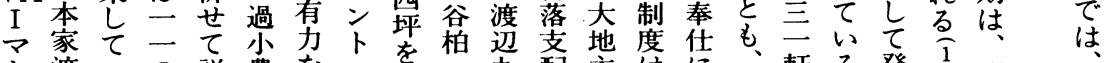

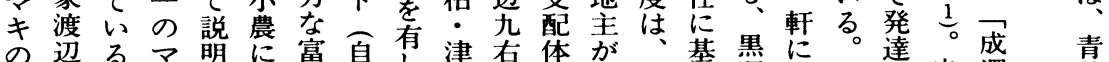

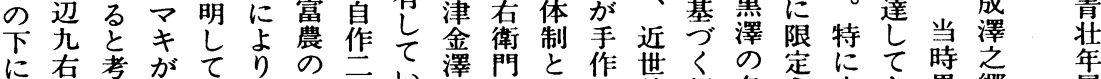

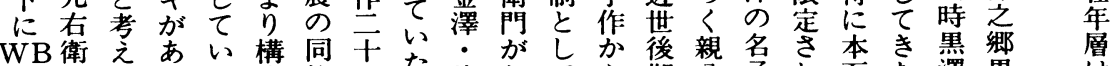

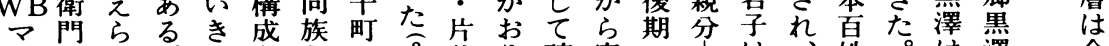

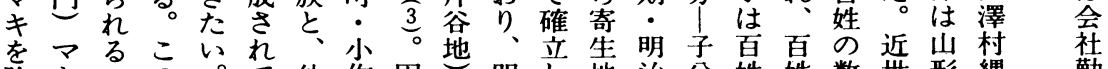
除キのの。他作因明地治分姓姓数世形縄勤 


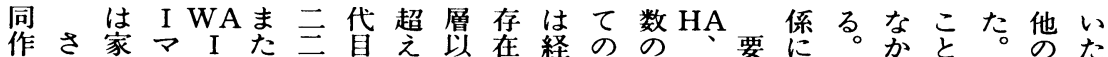
業て、会年のた上し済過自WB李応そつはそマ黑

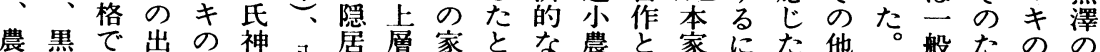
業澤選入家福分分階かい階がWA 順の事にめ構大 再はは衆が田代家層らつ層位I巨黒にマ実なに成多

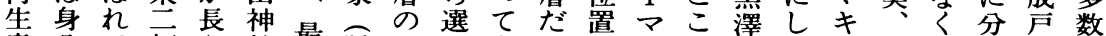

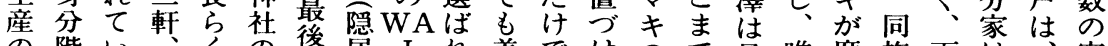
の階い後居Iれ差でけの最唯席族下は家 た層る及務氏照令るしなら出が聚一順内層全地が め制。び照がキの支くれ出夏同を部農全主属

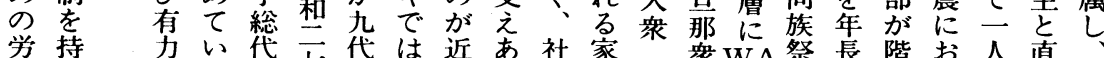
労持力い代王代は近あ社家衆WA祭長階お人直

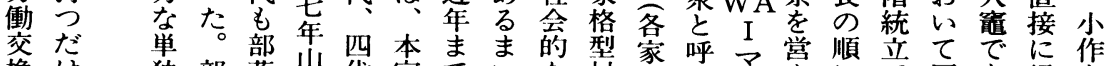
換け独部落形帒家でいな村のばキんにて同あ経を

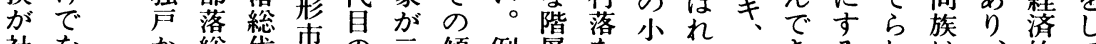

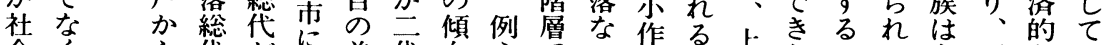

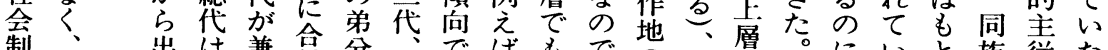

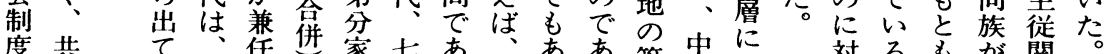

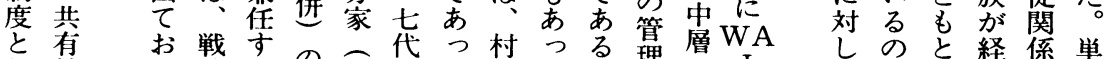
と有林後るの新垈つ村つる。理層WA L のと経係単

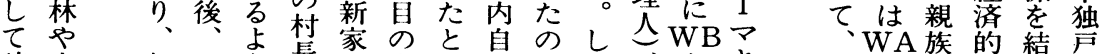

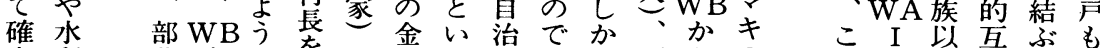

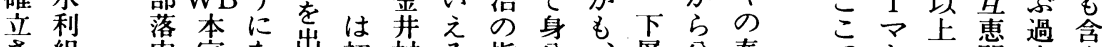
さ組家な出初村る指分、層分奉でキの関小め

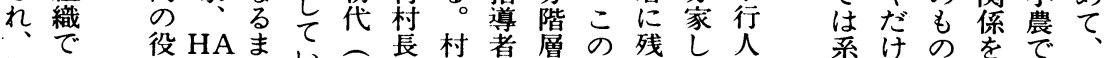
慣の職共い明落は制階りた分譜でで持あそ 行共者WA、る治三老落全小家関あはつうの

デ恩分た法村め察に代はる構に落す約表はの化

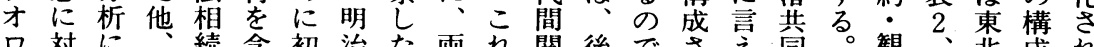
口対に、続含初治た両れ関後でさ之同る観、北成れ ギしよ教編め生民い制ま係述あれば体竹音表地単る 孝れ育にて等法。度でで守るて员内講 3 方位た ををば勅は殆相施の、ある。い黒部がでににはめ

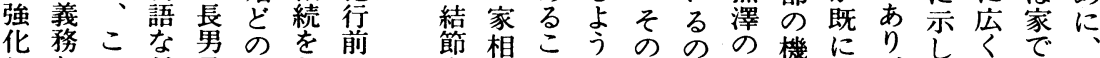

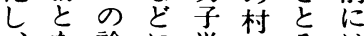
こし論に単落るは れ、はり相はが山 が 親、忠続長一地 やは親孝が男部方 がそ子の規子あに てれ間儒定相つも 天をに教さ続た。 袁利分德れでと業 臣と的济武 加経 のと格乼并た確営

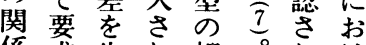
係求生れ相。れけ にし得さた続周るる でるせ特度の、働 搪家子に学よ責確 臺は川範に全保 れ的親島と たイののし同井た 点互とに意で場能指々た分あ村 とのに、味は合は摘そ。布り落

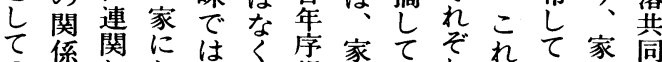

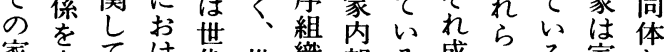
家家てけ代世織部る成のる家と を、格いる階代とのよ員各年格し 父制る竞梯合つ役う権階粚制て 関世代 社

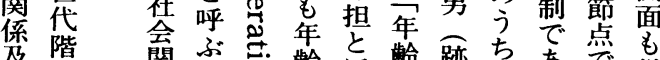

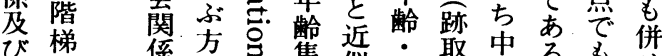
相制傃が集似性聚核る。せ 続か 家妥に団しに等的各る持 制ら長当よ行家組碏る。

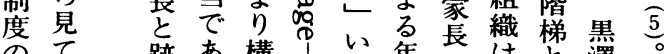
のて 跡あ構怘い年長は禁澤 側き取乃成导る序主若々㖕こ 面た りj。さ かがとに。織に組機同共 ら のこてょさの限・能組同 考次世れいり方村定契を織体 


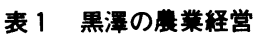

\begin{tabular}{|c|c|}
\hline 経営耕地面積 & 戸数 \\
\hline ～0.5ha未満 & 26戸 \\
\hline $0.5 \sim 1.0$ & 27戸 \\
\hline $1.1 \sim 2.0$ & 25戸 \\
\hline $2.1 \sim 3.0$ & 2戸 \\
\hline 専業農家 & 21戸 \\
\hline 第 1 種兼業農家 & 12戸 \\
\hline 第 2 種兼業農家 & 48戸 \\
\hline 計 & 81戸 \\
\hline
\end{tabular}

表 2 黒羁の年序組蜼

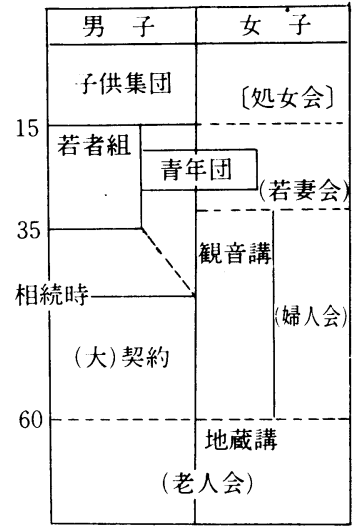

\section{表 3 黒㵋の年序組壦の膱能}

\begin{tabular}{|c|c|c|}
\hline 年序組織 & 従来の機能 & 現在の機能 \\
\hline 若者組 & $\begin{array}{l}\text { 1) 灭災防止のための夜回り } \\
\text { 2) 稲刈りの時期小屋に泊まり稲の番 } \\
\text { 3) 福田神社、氏神祭典の執行 } \\
\text { 4) 台力サリの門立ち } \\
\text { 5) 年一度の総会 (契約) }\end{array}$ & $\begin{array}{l}\text { S .29より山形市消防団に改編 } \\
\text { 1)消防の演習 } \\
\text { 2) 春・秋の夜回り } \\
\text { 農家の青年層が少ないため団員不足 }\end{array}$ \\
\hline $\begin{array}{l}\text { 契約 } \\
\text { 〔大契約 }\end{array}$ & 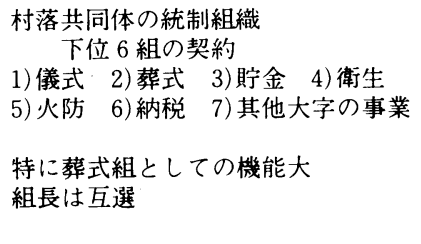 & $\begin{array}{l}\text { 部落会 } \quad \text { 下位 } 6 \text { 組の契約組 } \\
\text { 機能は殆ど変わらないが、部落下部 } \\
\text { 組織としての連絡機関の性格を強め } \\
\text { る。 } \\
\text { 組長は回り番 }\end{array}$ \\
\hline 観音講 & $\begin{array}{l}\text { 葬式の世話、御詠歌をあげる } \\
\text { 一軒で主婦一人が加入 }\end{array}$ & $\begin{array}{l}\text { 加入率48\%〔有効回答数78〕 } \\
\text { 地蔵講への加入率は } 48 \% \text { 〔同43〕 }\end{array}$ \\
\hline
\end{tabular}

表 4 相続の実態

(\%、カッコ内は実数) [パーセント表示]

\begin{tabular}{ccccccc}
\hline 前世帯主 & 長 男 & $\begin{array}{l}\text { 現世帯主 } \\
\text { 次 }\end{array}$ & $3 \sim$ & 長 女 & 婿養子 & \multicolumn{1}{c}{ 計 } \\
\hline 父 & 58.1 & 10.8 & 5.5 & 1.4 & 8.1 & $83.8(62)$ \\
母 & 5.4 & 4.1 & & & 1.4 & $10.8(8)$ \\
父の父 & 2.7 & & & & 2.7 & $5.4(4)$ \\
計 & $66.2(49)$ & $14.7(11)$ & $5.4(4)$ & $1.4(1)$ & $12.2(9)$ & $100.0(74)$ \\
\hline
\end{tabular}

註 父の父に対する現世帯主の続柄は 1 世代下がった直系尊属親に対する続柄である。 また、オジから継いだ人が 1 人いたが、この表からは除いてある。

$39(2 \cdot 23) 123$ 社会学評論 
梯共く、父残置た父に菓経那係地符係てを願きの 共同、名親存・なが示守営衆は解戦契がも誇と続で に体ま中をさ相ど幼しる上と消放後約成集る寄恬あ 機とた二敬せ続の小た形の二滅に的た立約病る 能し家四したの理時。で理般し よ墨よし的めに没 8

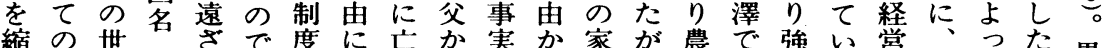

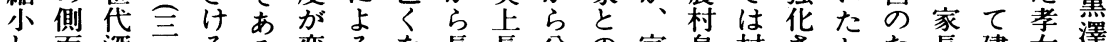
し面深三るる変るな長長分の家身村さとた長建女睪 てに度公心。わもつ男男割格の分落れ考めは妾か い注が、境例らのたが子相差経階家維えに家さん族れ る自深七に之なでな相単続は済層家維ら家族れの孝

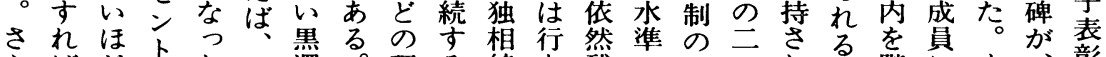
らばど士た跡澤。理る続な残の基亏れるす階にま貝彰

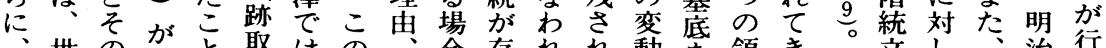
世のが取はの合存れれ動を領きき立し治行

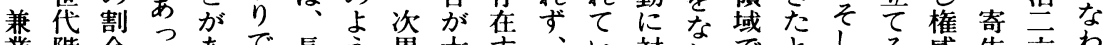

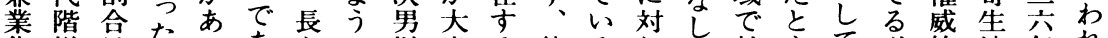

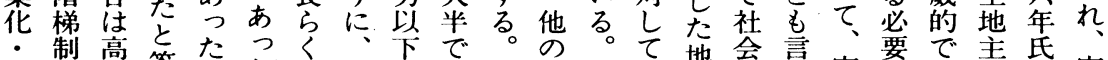
機は制高答ななた家村ので現キま家主構芝家要で主氐家

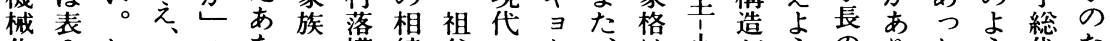

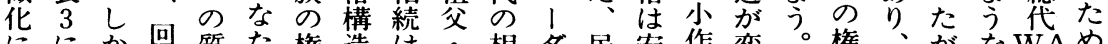
ににか回質た権造は、相多民安作変。権、等な゙Aめ 伴示し答問は威に長母続イ法定の化威家有I いしな者に家主占男かのが改し経し は父過力四 たがの甚義めがら実相正て済て 村長小声キ農通ら年世で的るしの態続後お的い落的農で三歳

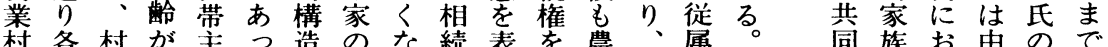

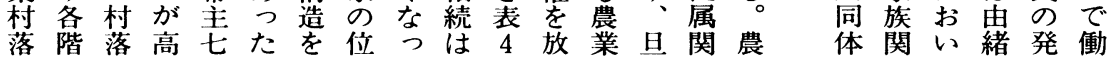

較はるの

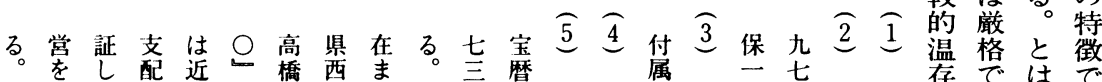

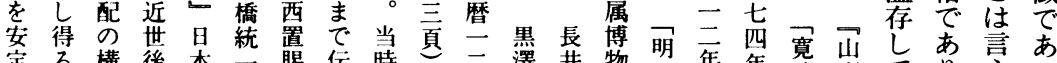

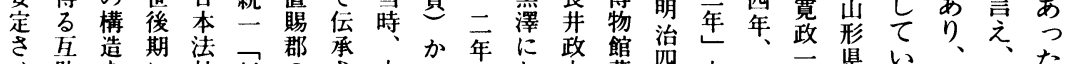

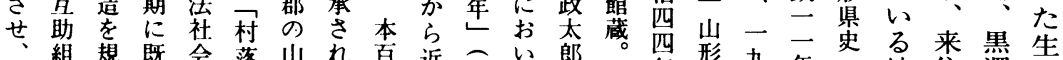

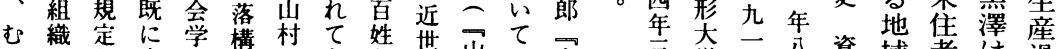

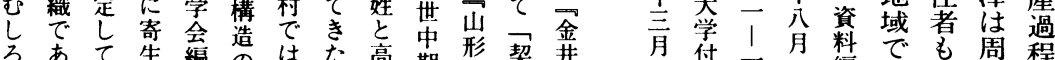

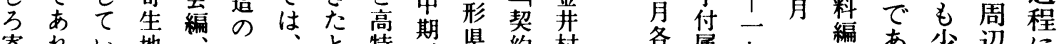

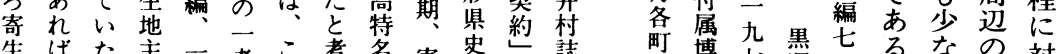

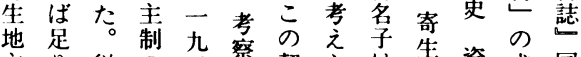

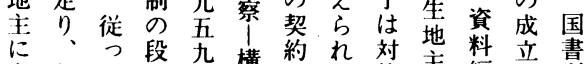

ま契て、階年造組る等主制編 は章 作内約入

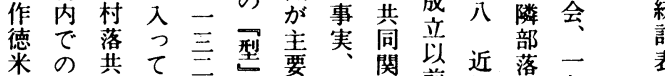
の平同お长要地係前世洛九 取等体り、五関社主型結邀資料想塄䢞 確権過土地頁て係落でるこ谷年

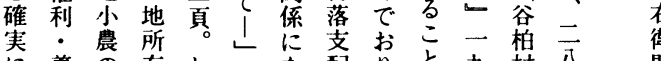

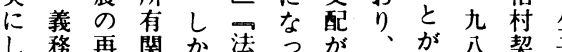

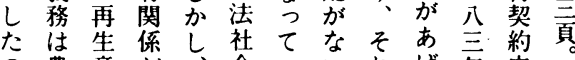
の農産が、会いいれげ年定。形

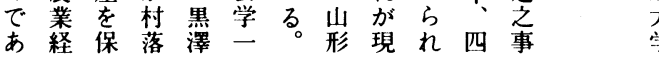
村物 七 澤 別物貪禁検。地忘 有咸墨出帳㤎比た 地澤明一笛一比年 村縟九旅九 中 計 宗竞德契行

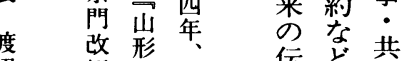
经県統と同 九 掣史 分 的関行

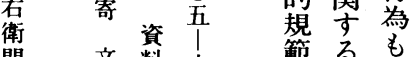
門文料六範㐌竟 山 华編立 制共退 形年三頁度体し 学天一比制い 


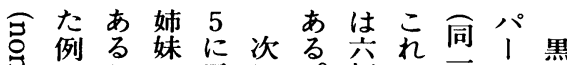

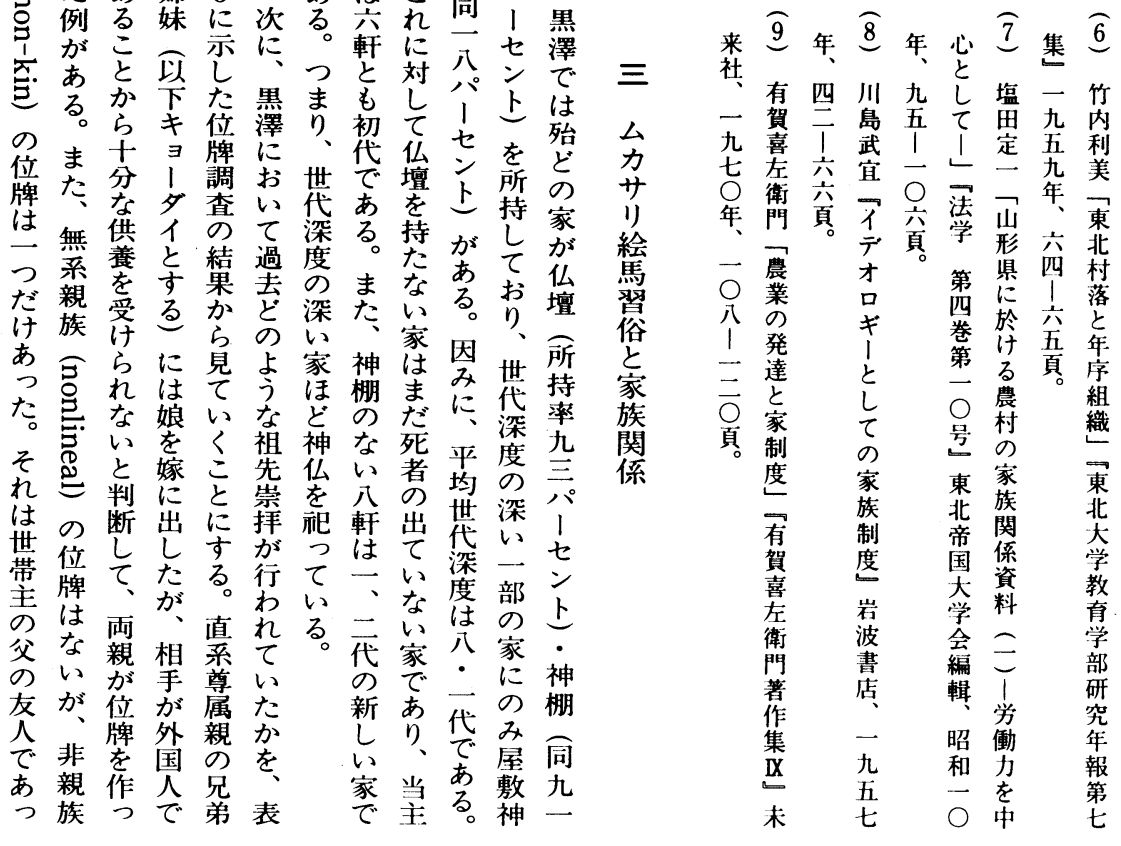

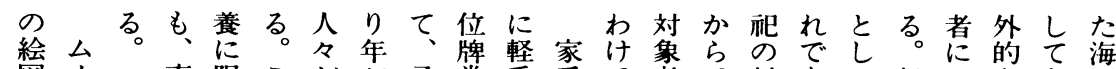
図力直限こがが子堂重系で者で対あて但のなま軍 を系らの、ず供离の継はのあ像る過しみををた軍 奉りとれよ家れのの差承な境つはが去、限の新属 納と傍たう長た四寺が者い界た家、帳一定としの すは系こにだ複割位生と。は。の非にケさ言い位 る方尔系う数气牌じそ明ま者親記、机家牌

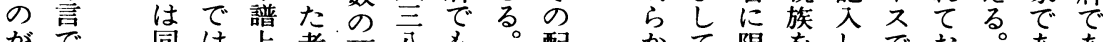

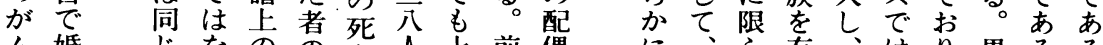

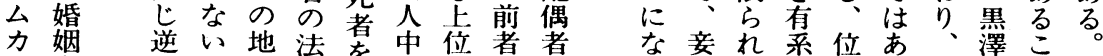

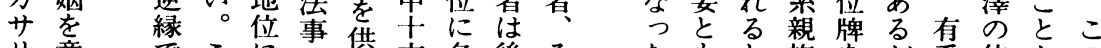

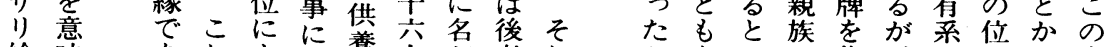

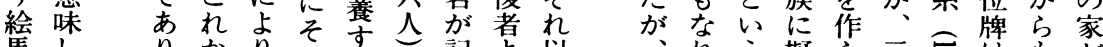

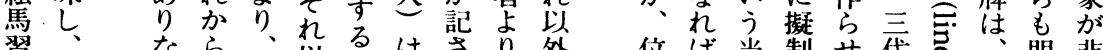
習、なら、以场はさり外位は当制せ代豆は、明非 俗末が述祭外会士れ立の牌な該した前き当ら農

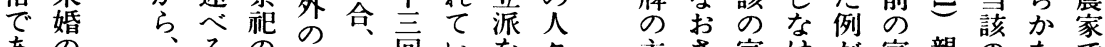
あのるの主さ家けが家親のなで

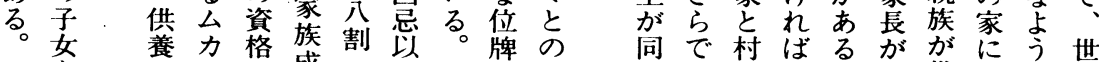

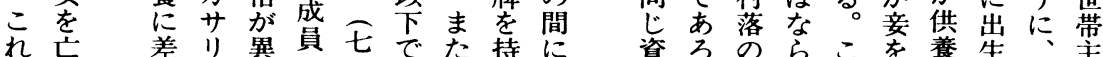

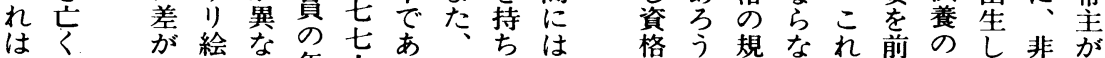

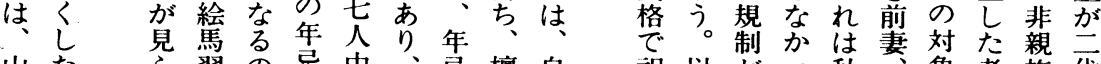
山た ら習の忌中、忌檀自祀以がつ私象者族代 形親れ俗はを六年法那子゙ら上動た的本にと自

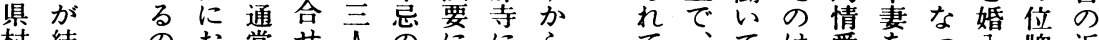

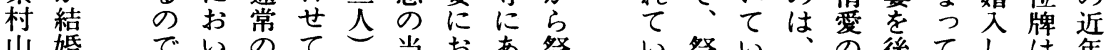
山婚でいのて当おあ祭い祭いはの後てしは年 地武あて供いのたいる形るる施た祭表妻いた例越 


\begin{tabular}{clrrr}
\hline & 位牌の類型 & & & \\
& & ある & なし & $\mathrm{N}$ \\
\hline \multirow{2}{*}{ 〔有系親族〕 } & 直系尊属親 (世帯主に対し & $87(98.9 \%)$ & 1 & 88 \\
& 直系卑属親 & $38(43.2 \%)$ & 50 & 88 \\
& 直系尊属親のキョーダイ & $50(56.8 \%)$ & 38 & 88 \\
& 直系尊属親のキョーダイの妻と子 & $7(8.0 \%)$ & 80 & 87 \\
〔無系親族〕 & 直系尊属親の妻のキョーダイ & $0(0.0 \%)$ & 88 & 88 \\
〔非親族〕 & 友人 & $1(1.2 \%)$ & 86 & 87 \\
\hline
\end{tabular}

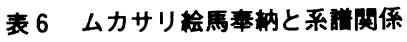

（）の中は小寺·若松·黒鳥を含めた全体

\begin{tabular}{|c|c|c|c|c|c|}
\hline \multirow[t]{2}{*}{ 被奉納者 } & \multicolumn{2}{|c|}{ 奉納者 } & \multirow[b]{2}{*}{ キョーダイ } & \multirow{2}{*}{\multicolumn{2}{|c|}{ 計 }} \\
\hline & 父 系 & 母 系 & & & \\
\hline 直系 & $8 \quad(17)$ & $0 \quad(1)$ & $1(3)$ & 9 & (21) \\
\hline 傍系キョーダイ & $0 \quad(4)$ & $2(6)$ & $1(7)$ & 3 & (17) \\
\hline 計 & $8 \quad(21)$ & $2(7)$ & $2(10)$ & 12 & (38) \\
\hline
\end{tabular}

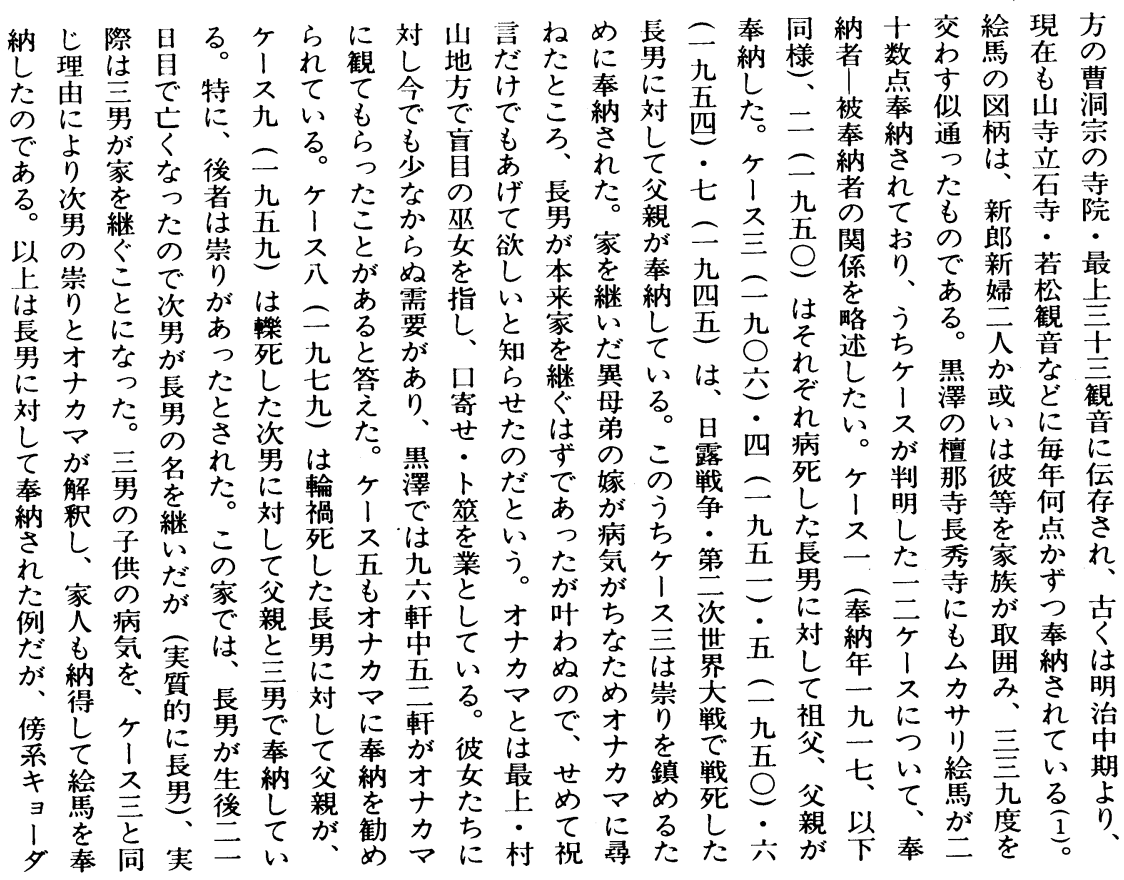




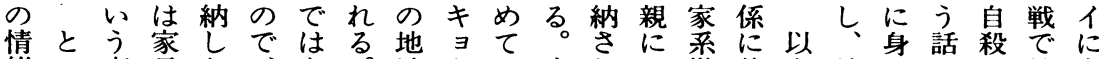
緒こ事長た、な。域 見次れの継着上結をがし戦奉 的乃実のの実い家に多てにてみ承自述核投あた死納 結では名も際だ長はイい長い奉者し心でげり、長しさ 合、、で含のろは父にく秀る納で、てした、姉たれ は家家、まとう跡と納と寺。しあままくと姉の至た

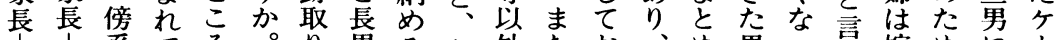

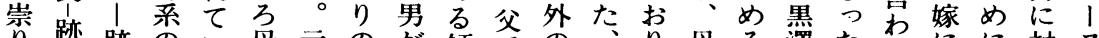

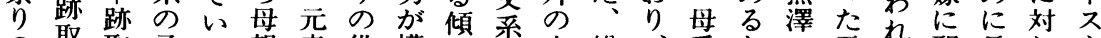
の取取子る親来供構向は山総、系との五て邪長しも

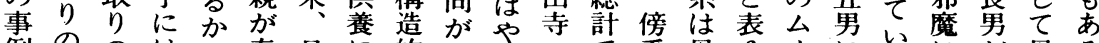

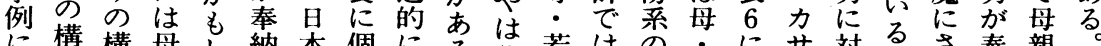
に構構母し納本個にるり若はの・にサ対る。さ奉親

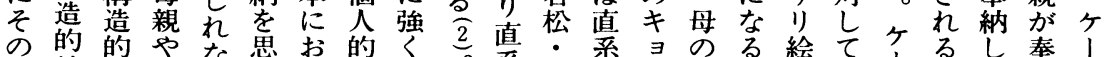

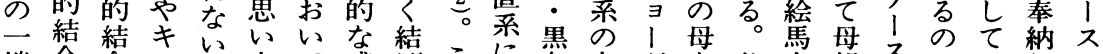
端合合 $\exists \frac{3}{3}$ 立感はこに鳥方多を父奉親スでいし二 表母歪多。ち、母情れ理母観多に含系納が二はるるた。 れと定イそ家の超家由系音くは。い自々 二 て子し自れ長情之父と及堂奉母黒父奉し二か殺 い供な身にや緒た長しびか納采澤公納た夳と等 る及いのしし跡的責的て キらさや゙父者。三、理二分

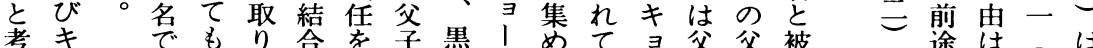

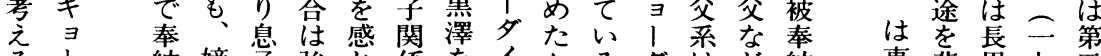

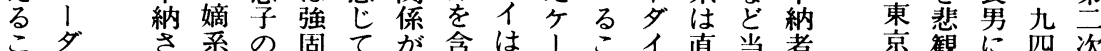
と页れの名でい想め傍不とか系該と者にし嫁二世

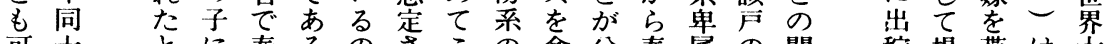
可士とに奉るのさこの含分奉属の関稼堤貫は大

崇こめケ方ケる。らち分ら気た長とそな崇識家だ信事能

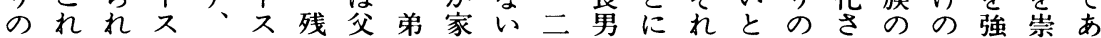
対らたはケ五り親にをこはがしで思理れ解理めりる 象未も、।でのが供継と子次たはわ问る秎由た・。 ・婚の一スはケ、養ぐの供男い、れはの図があ知崇 理ので九卆、そを作のの。黒るここで式あるらり 由死あ七でのスう要き因病妻ケ澤。れあにり種せと

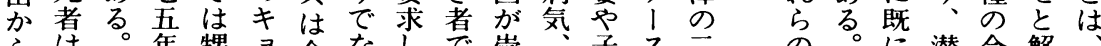

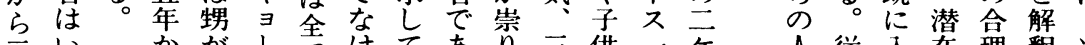

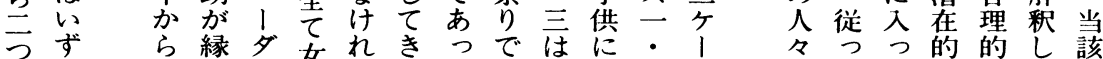

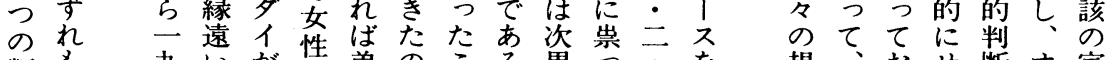
類も九いが性弟のこる男う立を規、㧧断才家 型婚公こ縁崇がでとと本た三除 型姻五々遠崇施あを解人とはい 措を年のいて主る理翻が解黒た

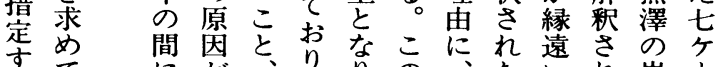

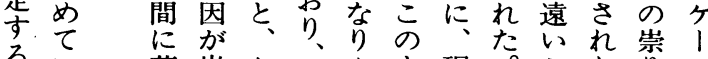

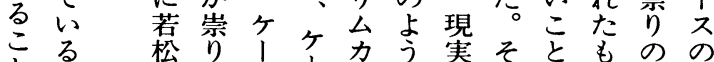

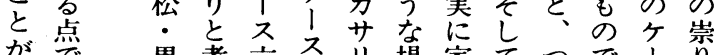
がで黒考六不り場家てつで! 可 可は鳥之で四絵合を、まあスの 能同等らはで馬第そ断る同事 でじすれ市れはを父いれ縁。様例 る。観た親姪奉親だぞ談者萻見

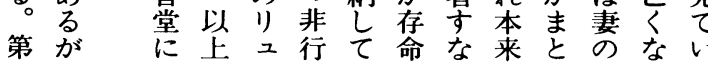

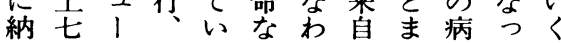

範 崇りよでナ族 意 ク、顕あ力が 識のそ在るマ家 に経れ的とな族 連路がに言ど成 関は一せ之の員 て当つなるる。起 以家事崇つ1 る族件らまマつ と成をれりンた 考員契る、の非 之間機可崇言暴 差関明性にに的 し係確ははよな 支にに当崇り出 之意該る確 来 
持要に囲を崇の案不機等能が礼い者で女り、りは、

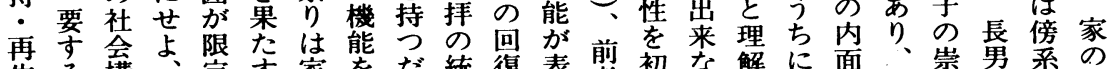
生る構、定家をだ統復表湟初な解に面、崇男系の 産に造本さ他長果け制の机者めかさらが結り子で構 等、節れ面のたで的たて関かつれく死婚の相あ造 る制反でても法しな機めい阅らたてし者で対続り的 機度映述いあ的てく能にるるて持といてにき象のな側 能としへるる権き、と、とはついるし代なは断が面

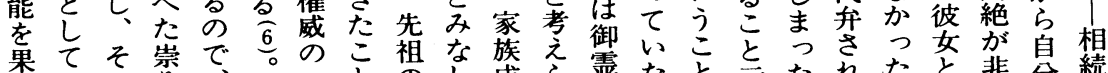

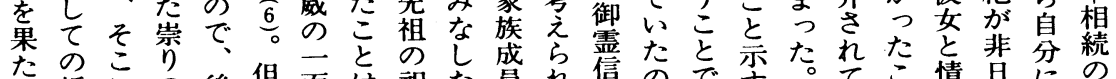

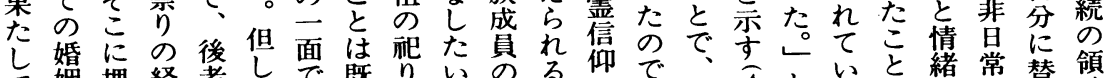
て姻埋経者しで既りいのる仰で、市とい緒常替領

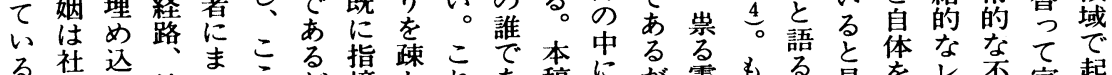

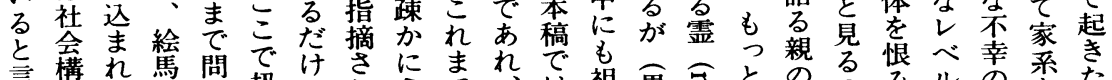

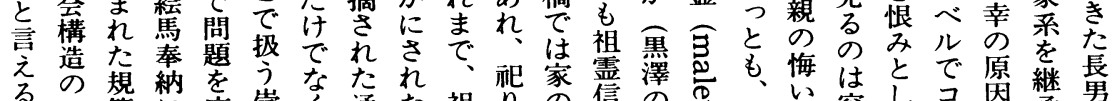

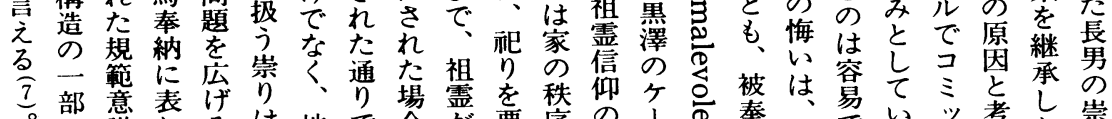

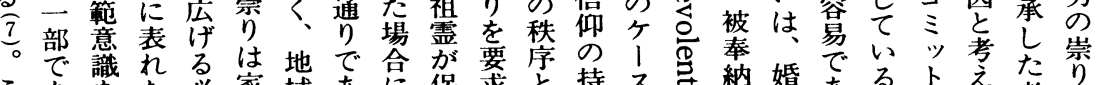

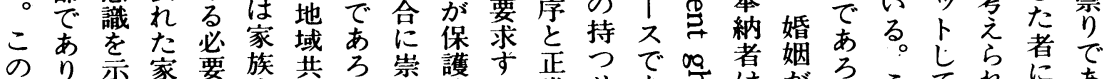

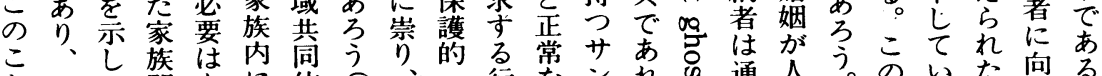

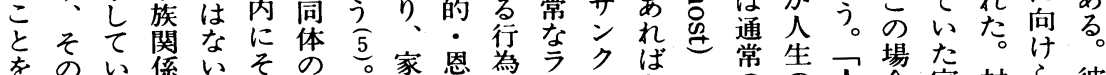

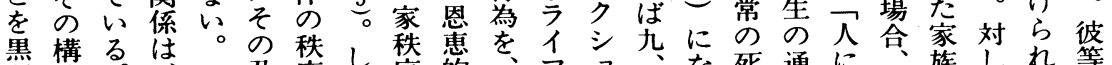

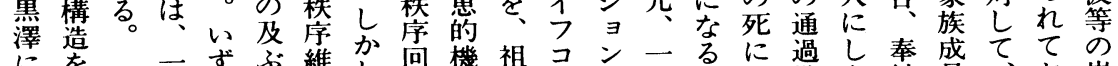

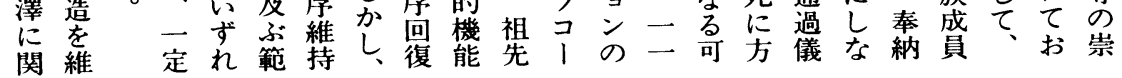

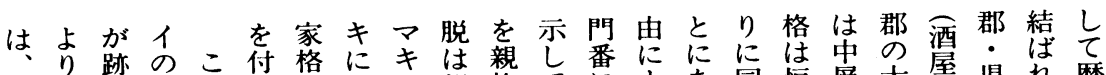
家妥取場の㚓分絶で親族てによあ同恒層大屋県れ歴

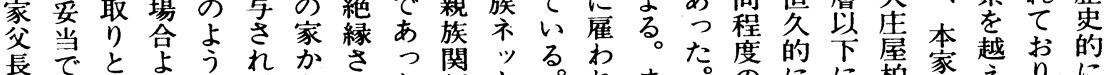

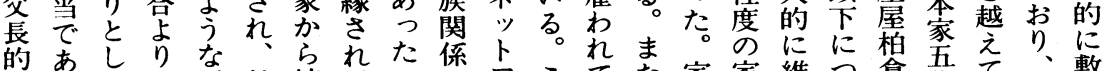

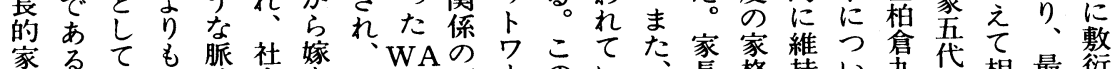

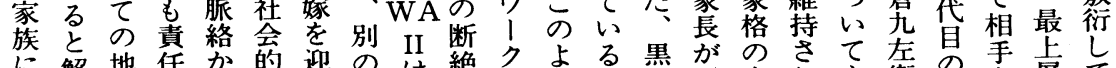

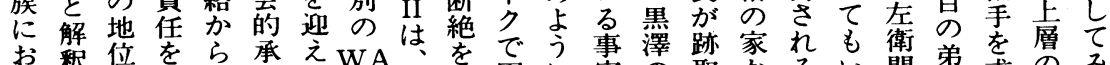

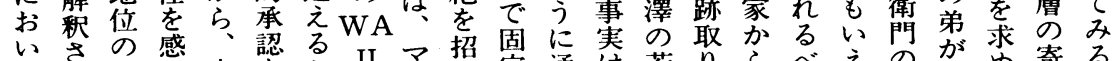

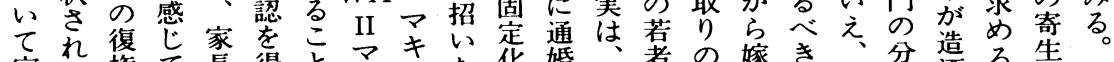
家た権て長得と令まのた华娨家組配を嫁き村芜酒る倾地里

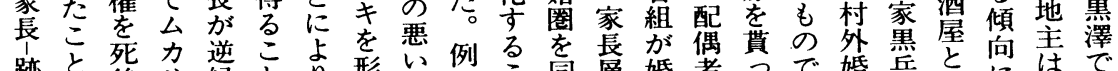

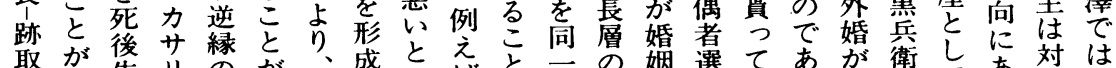

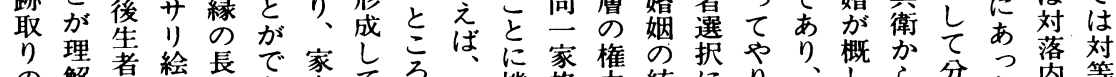

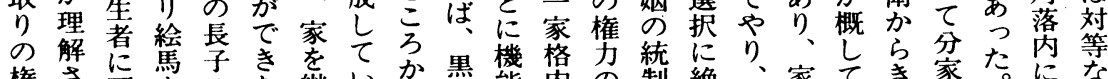

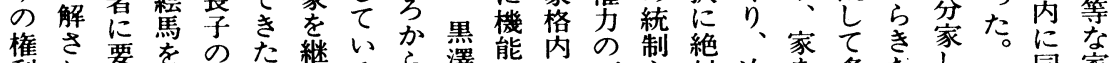
利れ求奉婚の承る。嫁に摆に態主対恣多たし因同家

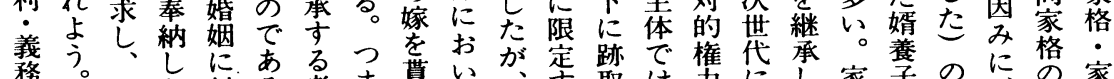
関么そた対る。者ま貫いが宗跡で権帒承家養のに年家

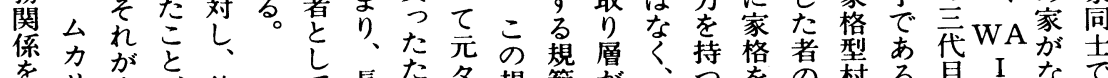

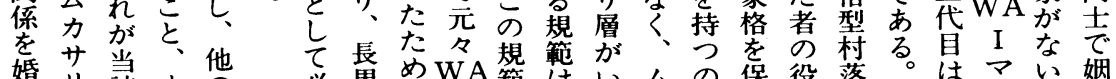

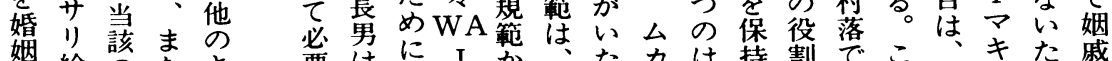

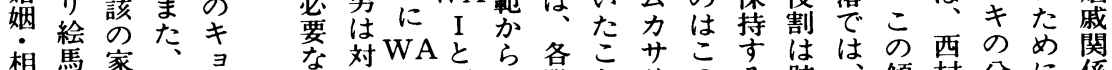
相馬家習族長 1 資等 I 同 の階と少の方跡傾村分に係 の俗に男夕格なマし逸層をの理こ取家向山家、か 
七. $\widehat{5}$

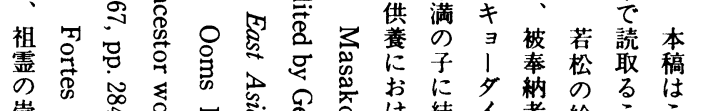

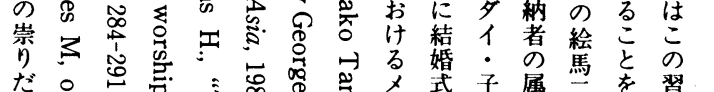

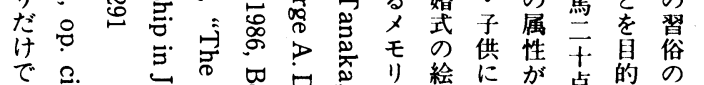

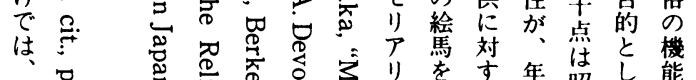

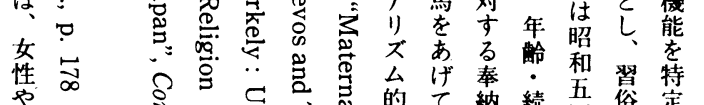

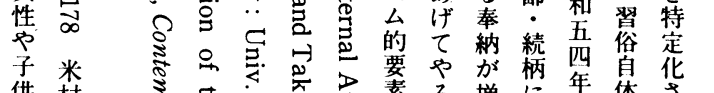

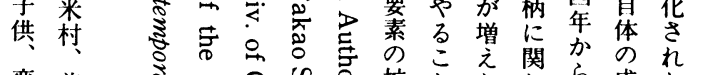

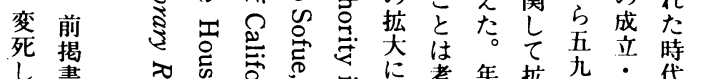

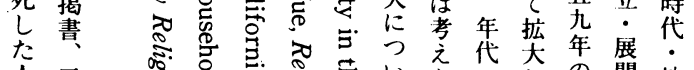

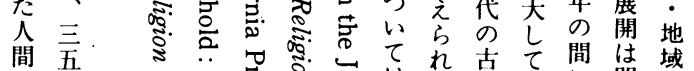

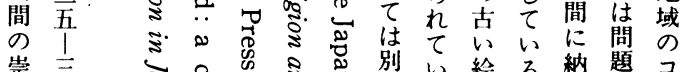

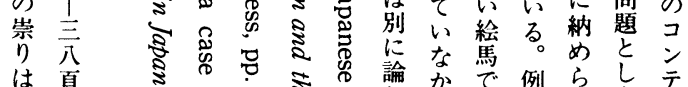
は頁

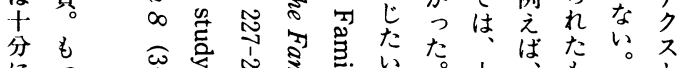

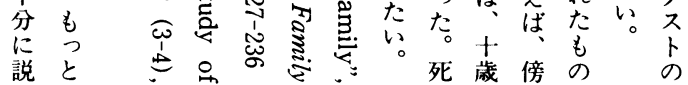

スれにに家はう制

にたも供系京度

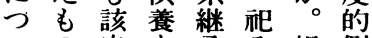
いの 当を承る 祖側 てでし要を者先面 もあ、求予と崇に 黑る大し定祀拝お 澤。地合さらにい とそ主えれれせて 同れ支るたるよ回 様故配の長者、復 の、・で子と逆す こ若世あとの縁る と松代るの生の儀 が・階。関前天礼 言黑梯黑係の逝で え鳥制澤は世者あ よ・はの咅代のつ う山こ社恵間供た 寺 の会的 関養 と か地構な係に見 ら域造もをせる

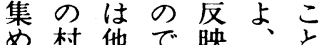
な村他で映落の点 絵に村るてれ可 馬一山たいら能 奉 般地めるので 納的方に。宗は のにの、家教な ケ見村 相長儀 か

でのだにス考配及う

系い人数方偶 びか。 1

譜㫫と種息 $\mathrm{V}$ にはま現 上にと類る で限先ず在

始対自先々、妻て 祖先責

祖応分祖 II 方心系祖䕉 をした観と親る。譜観に

先て ち が IV 族。上かお 祖心の存が家在黒でれ始見て をる家在墨でれ゙始見で る、祭たの 含対にいの

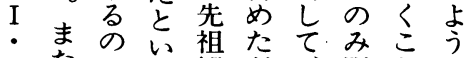
II たでう観双、限と学 は世な説を系 IV 定に祖

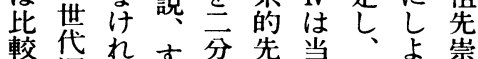
的深ばす分先当類う择 浅度、なて 観の型。が いの何わおで家 III 表行 。深処 、りあ族は 7 な こいで家柳る成家のわ れ先家柳家系先れ は祖他の思各を継祖て 観で最の類全承観い 黒がは初古型て 者のる 澤 III 祭の来の 先と類の で・る人日ケ祖そ型だ は IV 者た本、との I ろ

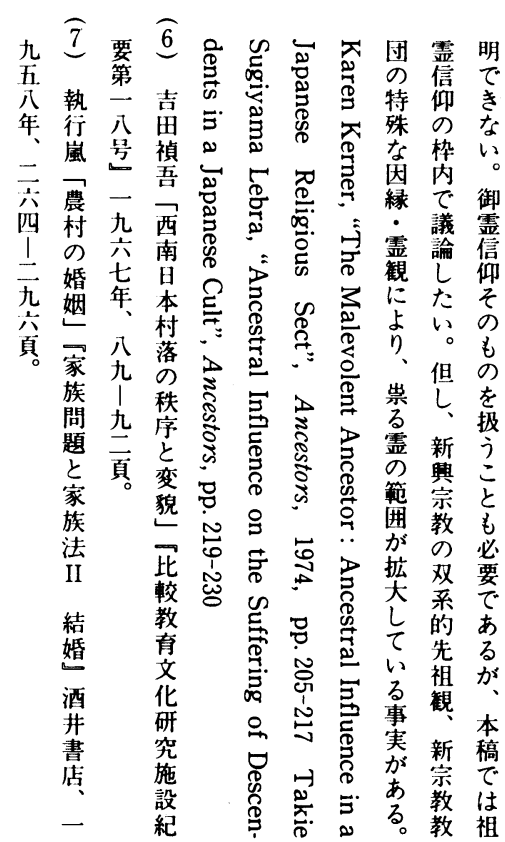


る言 とての毎と占了きはj牌上父も実識意祖にれ的

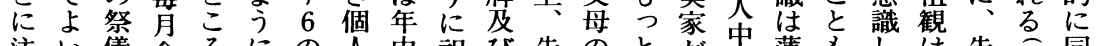

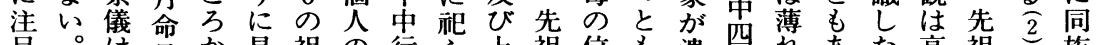

目。和見祖の行ら祖位も潰四れあた高祖。族

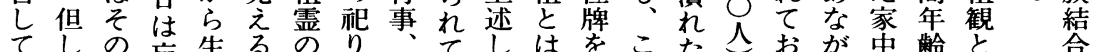
お、家志心祀で 4 いた誰置れ場がり、志層年品

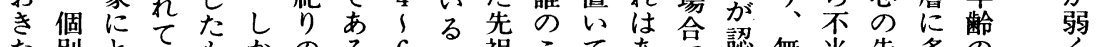

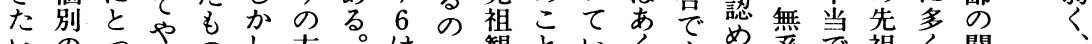

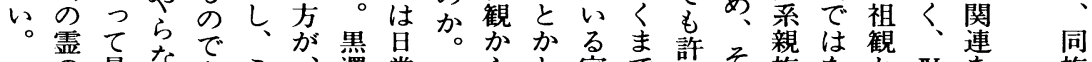
恶最なる、澤常表らと家で許そ族な僬 $\mathrm{N}$ 連族

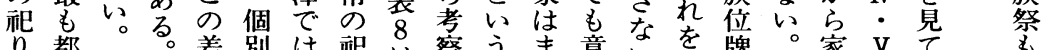

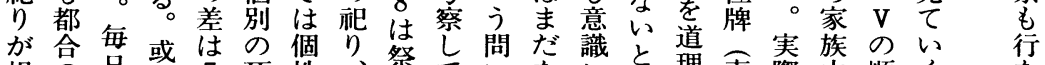

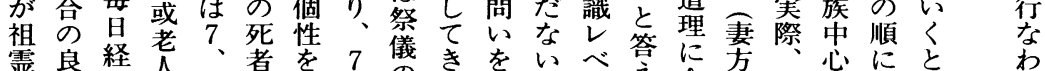

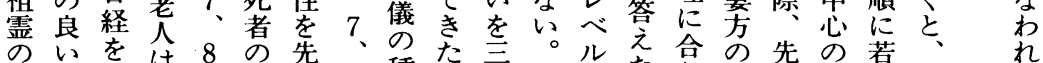

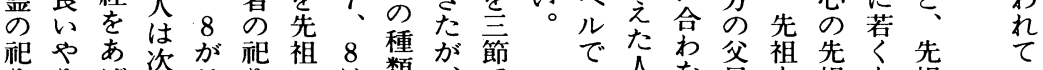

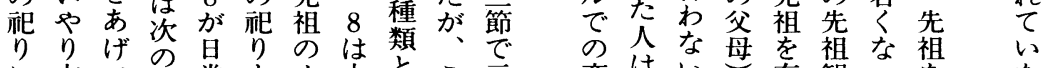

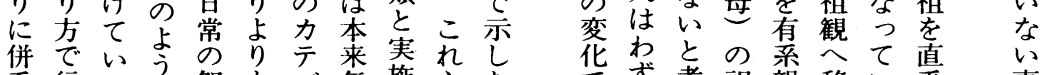

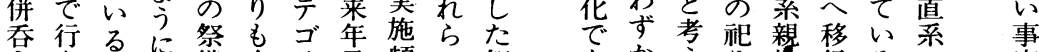
さな語儀多り忌頻の祭 あか之族行る。市実 れわら語に行!法度先儀り一要をに方。先に

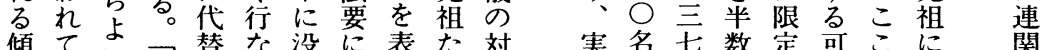
向いい。祥替な没に表た対実名等で数定可こに能に限祭

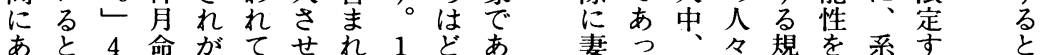

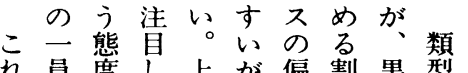
れ員度じた位が偏割墨型 ぞ考あでた位々差合澤一、 の之るの類の理亥祭つ 考占。は型理解三義ま 察れ先以圭由で分類り、 かて祖いもはき!型 ら、がた毎先る。七毎 るルだ朝に。帒晚 黒か、き述彼卜表の 䕪らテ祭述岸山少供 はでイの儀た・がる養 かあ、がを通毎高とを なる。化あ行通前い言除 伝䇗ないで合三てて、

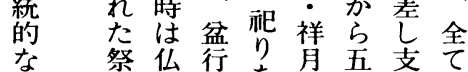
祖儀壇事を命ま方の 先のにも意白でな供 崇対あ滞つのはい養 帱象げりて祭類ほを をでてない儀型ど行 行はかふるは採等に な斿頙け省!全方 地、交でさル数先 域家とるはれコに崇 で族いななや小占洋
る的さ家るむ都う新者す

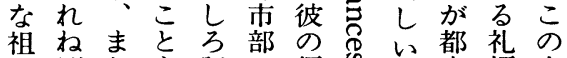
先ばたも記に仮名祖市洋点 崇なそ可憶は説号祖部のに 洋らの能に農をを先に類関 をないで新村導导崇顕型し ない行いするし部き怘洋著と個て

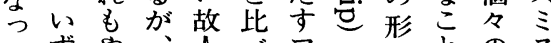

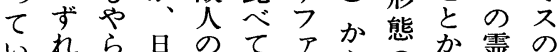

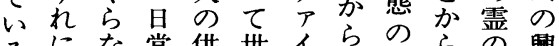
るにな常供世イら供萌ら、の興 のせいの養代ン供萌、剠味 でよ家祖が梁デ養芽祖り深 あ゙る尔先度々主を霊をい るス出崇にの義指の中指

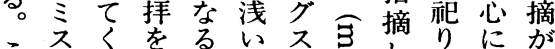

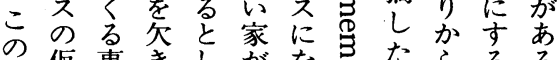
こ仮事きしがなる人たるる。 と説はが、て高別洋彼 は従、ら家たい鸹この類は 表之時追のめる隹れ死型祖 九は代善構に。へれ者と䨋 か桨䣏造祖ののは巷を晋 も墨澤養か祖の理变祖養䘡祀 言はら行説恶宙告とし、 い伝説な明りをと崇い、重 う統明うすもも择う後視 
表 7 先祖粯の類型

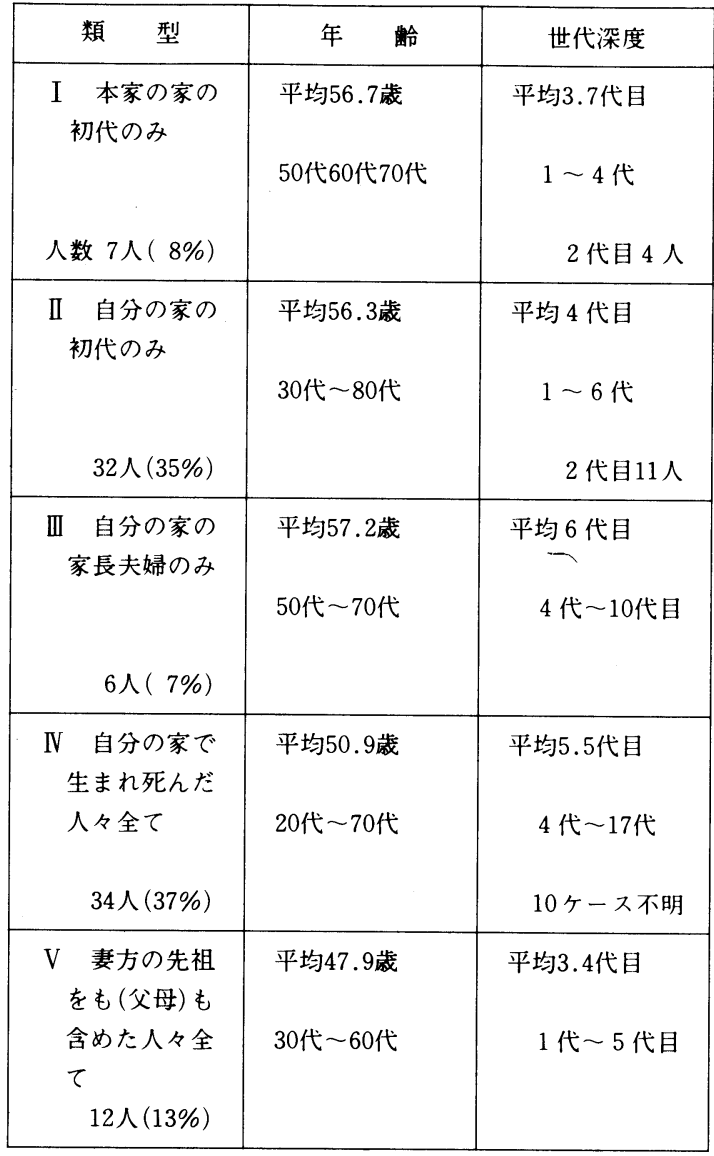

表 8 祭位の頖度

\begin{tabular}{|c|c|c|c|c|}
\hline & & & & （值は軒数 \\
\hline & 祭儀の項目 & やる & やらない & NA \\
\hline 1 & 盆 & $90(94 \%)$ & $3(3 \%)$ & $3(3 \%)$ \\
\hline 2 & 彼岸 & $65(68 \%)$ & $28(29 \%)$ & $3(3 \%)$ \\
\hline 3 & 正月 & $74(77 \%)$ & $19(20 \%)$ & $3(3 \%)$ \\
\hline 4 & 毎朝 & $85(89 \%)$ & $9(9 \%)$ & $2(2 \%)$ \\
\hline 5 & 毎晚 & $8(8 \%)$ & $85(89 \%)$ & $3(3 \%)$ \\
\hline 6 & いただきもの & $78(81 \%)$ & $15(16 \%)$ & $3(3 \%)$ \\
\hline 7 & 祥月命日 & $63(66 \%)$ & $30(31 \%)$ & $3(3 \%)$ \\
\hline 8 & 毎月命.日 & $50(52 \%)$ & $43(45 \%)$ & $3(3 \%)$ \\
\hline
\end{tabular}

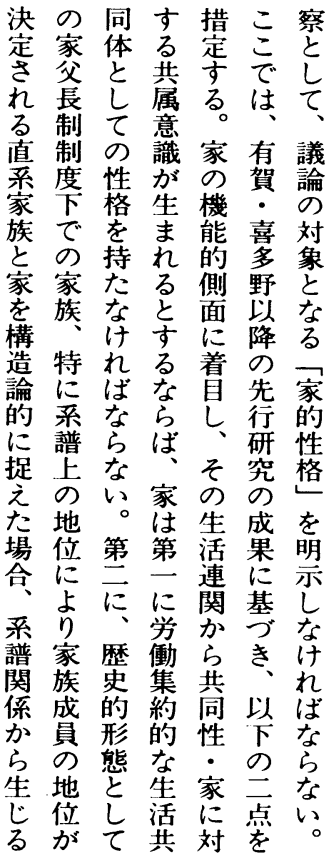

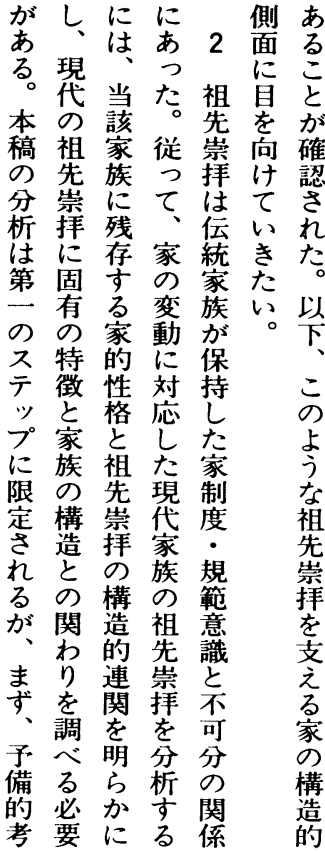




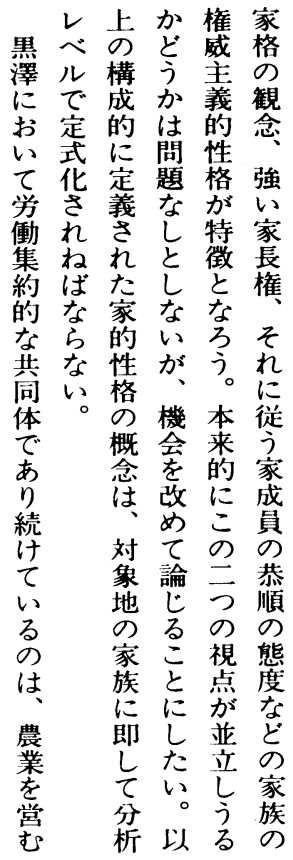

取のた働行家

り意心な族

と識家よつで

ア求の経いる。

ンめ観 営る

ビら念でがも

ウれはあ空

ア家本る竞ん

ン族家とな

卜の!な家現

な家分ど、産代

関訔関家あ農

係的係的る 村

な性性土家

格旧格地族

表は地をがは

表嫡主残生

系 系産近

よ傍作い段の

う系関るで家

の係可あと

当骖热能るは

然別 万性異

の家生芯と、

なと家。族営

が跡格ま労豈

\section{表 9 代表的な祭位の類型}

〔上位 7 類型 $\mathrm{N}=65(68 \%)$ ]

類型戸数 盆 彼岸 正月祥月 毎月 毎朝 毎晚いただきもの 命日 命日

があった時

\begin{tabular}{|c|c|c|c|c|c|c|c|c|c|}
\hline 1 & 32 & 0 & 0 & 0 & 0 & 0 & 0 & & 0 \\
\hline 2 & 8 & 0 & 0 & $\bigcirc$ & 0 & & 0 & & 0 \\
\hline 3 & 7 & 0 & 0 & 0 & & & 0 & & $\bigcirc$ \\
\hline 4 & 6 & $\bigcirc$ & & 0 & 0 & & 0 & & 0 \\
\hline 5 & 4 & $\bigcirc$ & & 0 & 0 & 0 & 0 & & 0 \\
\hline 6 & 4 & 0 & 0 & & & & 0 & & 0 \\
\hline 7 & 4 & 0 & & & & & 0 & & \\
\hline 計 & 65 & 7 & 4 & 5 & 4 & 2 & 7 & 0 & 6 \\
\hline
\end{tabular}

表10 祭㒕の項目

分類軸の意味 一:しない + : する

1 盆に祀る

8 いただきものがあった時に祀る

2 彼岸に剠る

9 盆棚を作る

3 正月に祀る

10 山寺へ後生車を納める

4 祥月命日に祀る 11 山寺へ歯骨を納める

5 毎月命日に祀る 12 観音講に加入

6 毎朝祀る

13 地藏講に加入

7 毎晚祀る

14 オナカマに観てもらった

数量化第三類第一軸を採用〔固有值 1 軸.281 2 軸.1503 軸.113〕

\section{表11 祭篗の規定要因 1}

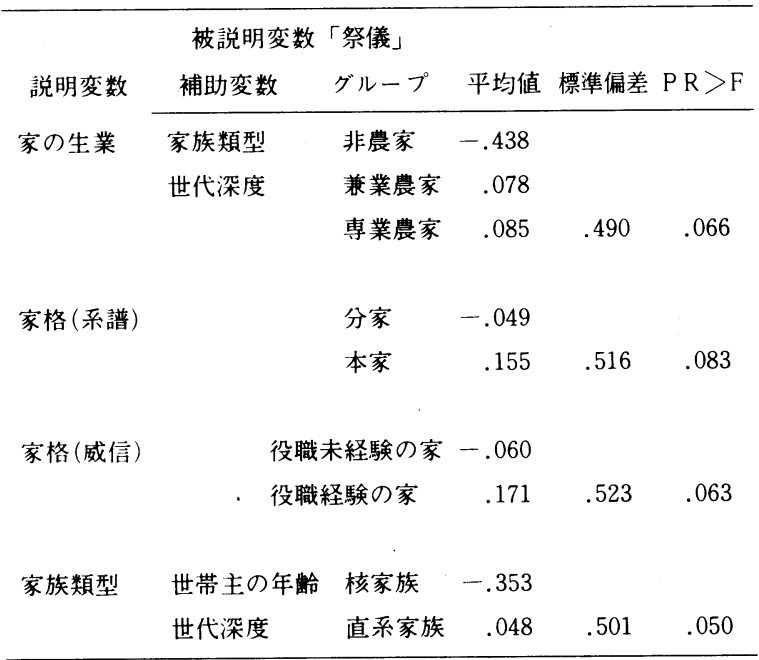


りあ祖が八成つはがそ拘世均尔なこ变け方族最家ら、 雇て崇家!期り、済兼にず哚をセが、に各説ど初存こ 用も拝的七以、的業対、度見ンあ表す項を家に在れ 者、が性ン降黒下農し集をる下る11る目検的家をら 世老伝格卜で澤部家、約コと未气か。の討性のあの 帯人統をにあの構は生的ン、満とら、祭標告格生と家

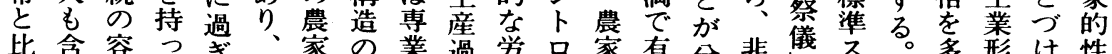

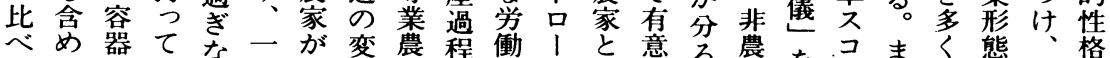

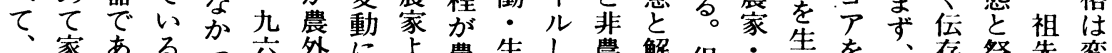
個家ある。つ六外に占農生し農解但并業を、存祭先変

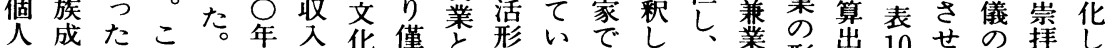
の員これ現当に構か農態るはてケ農形出 10 せ関棒し

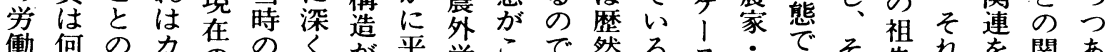

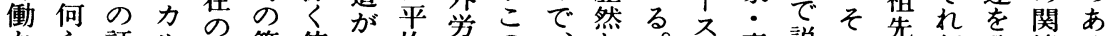
から証儿兼第依直均働の、と数専説の怠な゙分連る

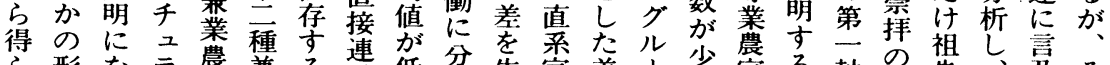
ら形なラ農兼る動低分離生家差、少蒙る軸項先先言そ る生う!は農うしな゙す出・あこい族な分総目崇労しの

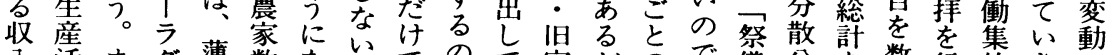
入活まグ薄数なかでのて家がので俄分を数行約きの は動たをめはつかあがいで、被有焦析量な的た二 家に起農たでる。兼るあ家説意の祭华っ経い局 全携兼气れ家のでる。業とる族明性分行㵶第て嫦。面 体わ業すて全は方々华言か類変水散な隹恶い密に のつ農ほは体、交ので之否型数準にうと類るななお

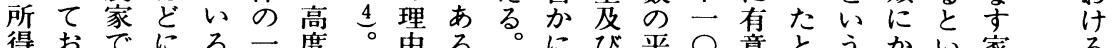
得おでにる一度。由る。にひ平 ○意とうかい家る

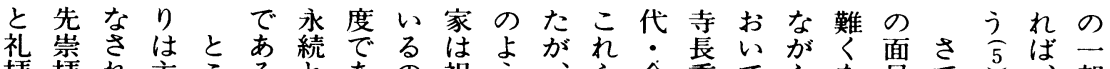

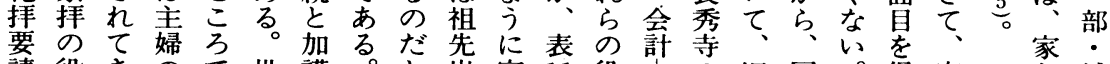
請役きので世護。と崇家11 役農の旧同。保家補

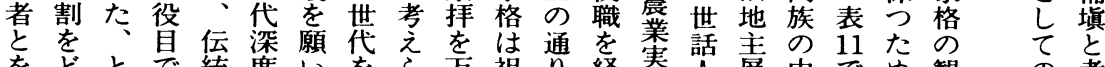
をどとで統度いをら方祖り、経筕人㲊中でめ観の考 対の言あ的と超れ端先、験行に組ににはに念 ま之

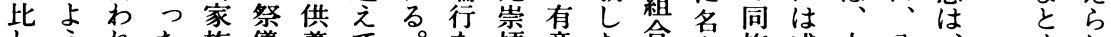

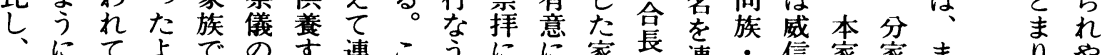

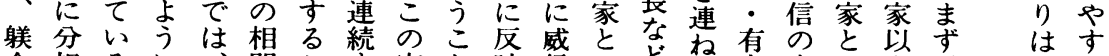

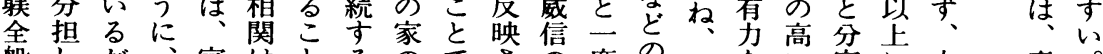

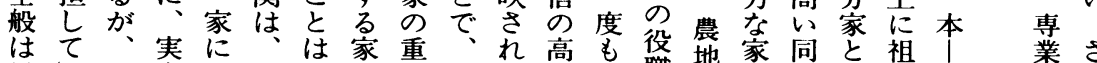

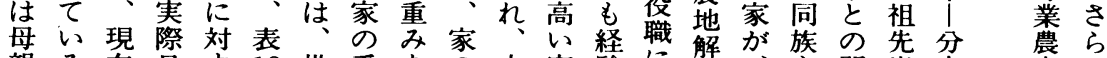
親る在昌す 13 世系を索本家験に解放間崇家家に

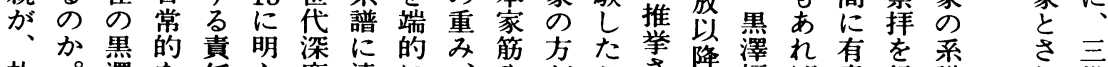

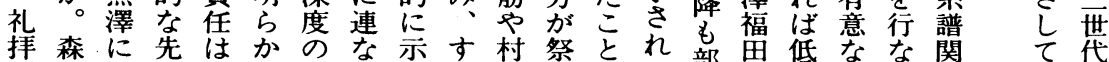
要岡お祖家で深るしな内義がて落神い低なな竞す係変蒙 請はいの長あい数てわに等ない洛社もがて这り族 者二て世にる家多いちちお行いる会ののみいにに

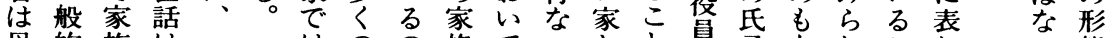
母的族は二 はのの格てうとと貝子あれこれ態

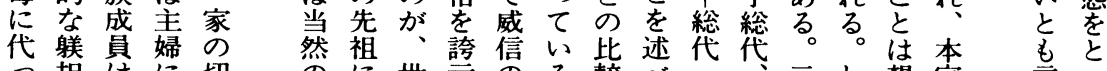

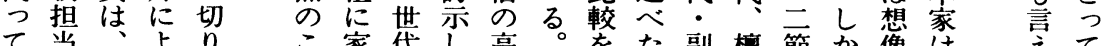

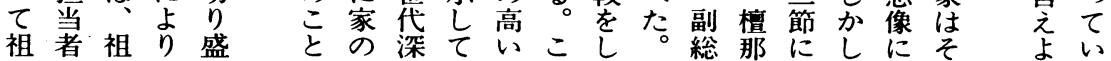




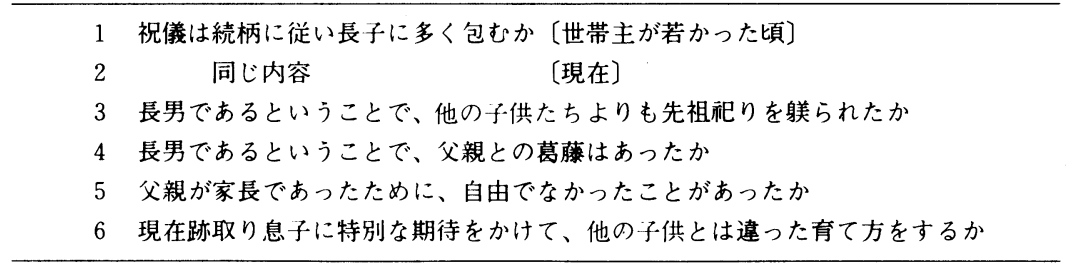

数量化第三類第一軸を採用〔固有傎 1 軸. 3652 軸.153 3 軸.133〕

表14 祭恶の規定要因 3

表13 祭篗の規定要因 2

\begin{tabular}{ccc}
\hline & $\begin{array}{c}\text { 「祭儀の実施」 } \\
\text { 相関係数 }\end{array}$ & \multicolumn{1}{c}{$\mathrm{P} \mathrm{R}>\mathrm{R}$} \\
\cline { 2 - 3 } 世代深度 & .363 & .001 \\
家父長的父子関係 & .215 & .036 \\
\hline
\end{tabular}

被説明変数「祭儀」

説明変数

世代深度

\begin{tabular}{crrr}
$\begin{array}{c}\text { 被説明変数「祭儀」 } \\
\text { 分数 }\end{array}$ & \multicolumn{1}{l}{ F値 } & PR $>\mathrm{F}$ & $\mathrm{R}^{2}$ \\
\hline 1.482 & 6.32 & .014 & \\
1.150 & 2.45 & .093 & \\
.858 & 3.66 & .060 & \\
.620 & 2.64 & .108 & \\
.228 & .97 & .327 & \\
.001 & .00 & .955 &
\end{tabular}

家の生業

\begin{tabular}{crrr}
$\begin{array}{c}\text { 被説明変数「祭儀」 } \\
\text { 分数 }\end{array}$ & F值 & $\mathrm{PR}>\mathrm{F}$ & $\mathrm{R}^{2}$ \\
\hline 1.482 & 6.32 & .014 & \\
1.150 & 2.45 & .093 & \\
.858 & 3.66 & .060 & \\
.620 & 2.64 & .108 & \\
.228 & .97 & .327 & \\
.001 & .00 & .955 & \\
& & &
\end{tabular}

家父長的父子関係

$\begin{array}{llll}.858 & 3.66 & .060\end{array}$

家族類型

.620

$2.64 \quad .108$

家格(威信)

.228

$.97 \quad .327$

経済水準

.001

$.00 \quad .955$

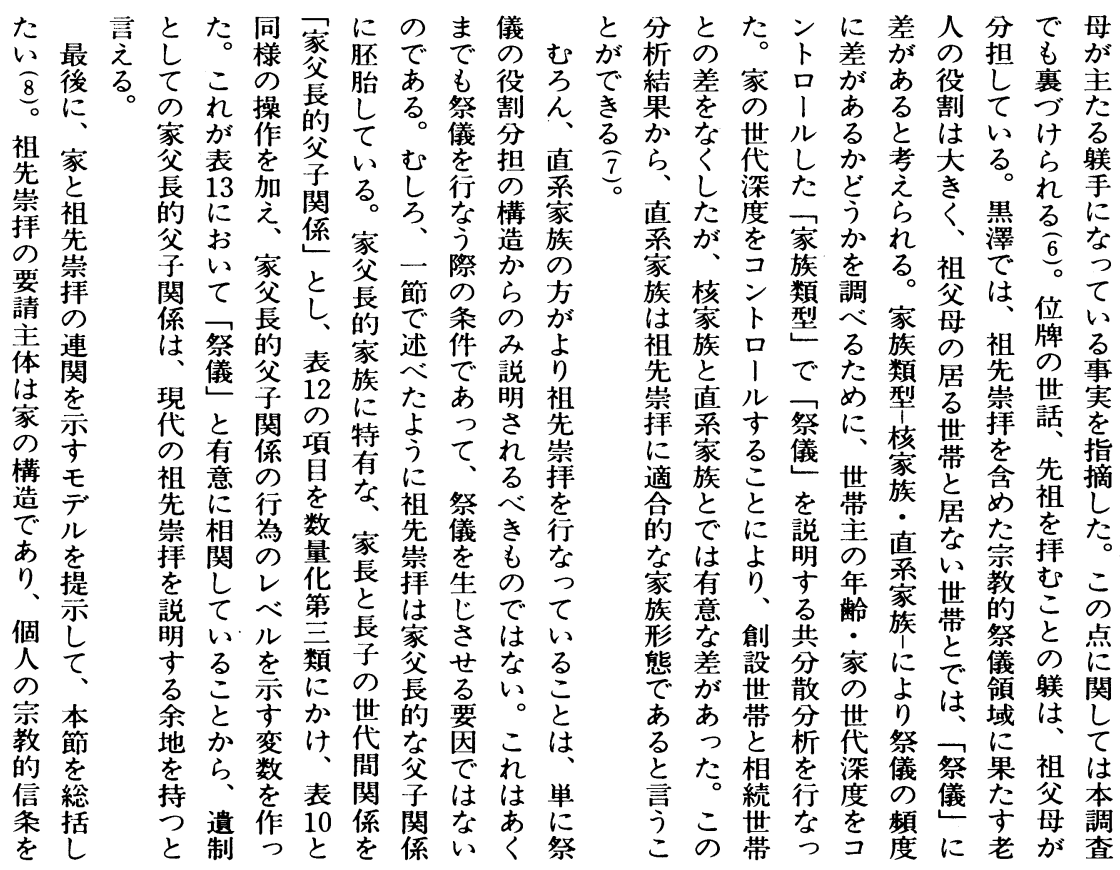




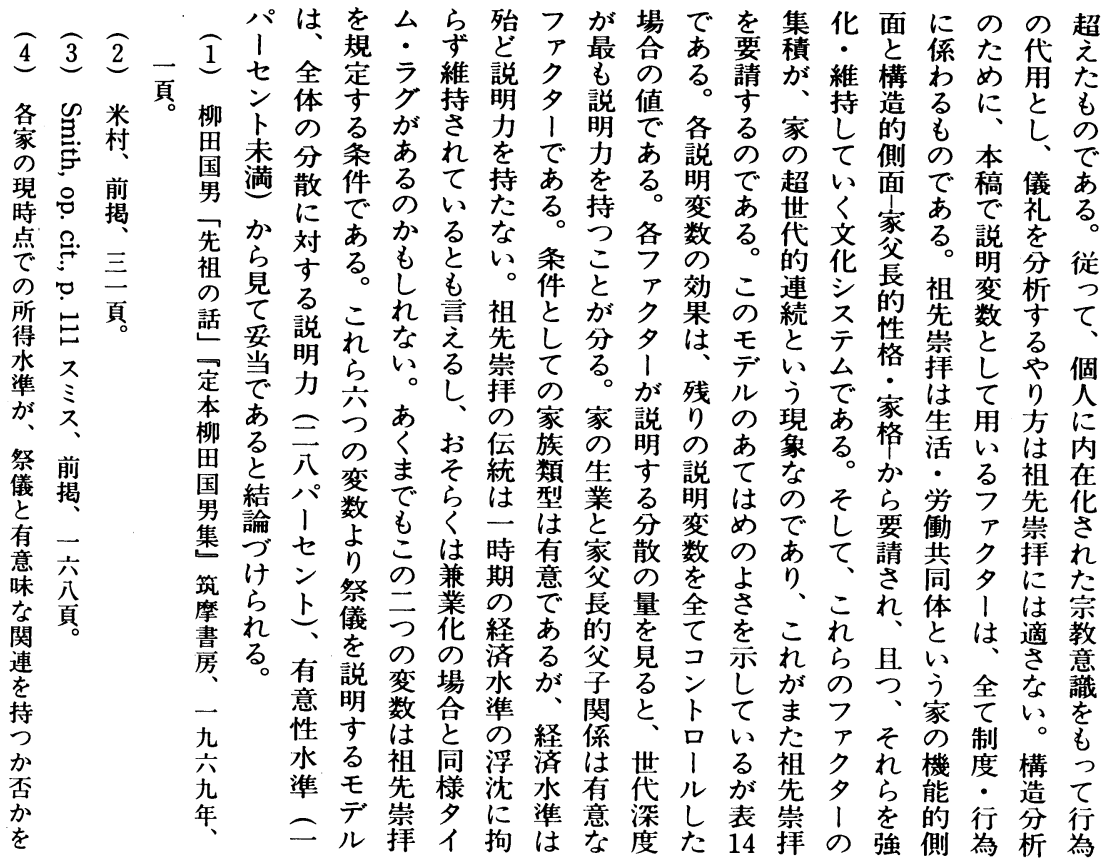

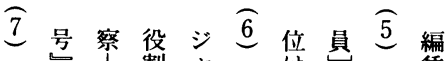

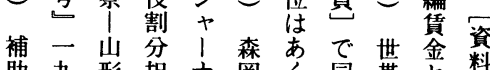

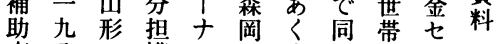

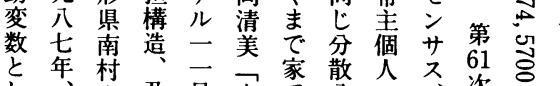

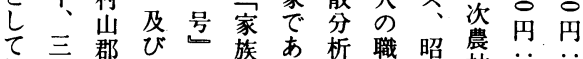

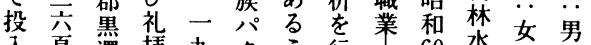

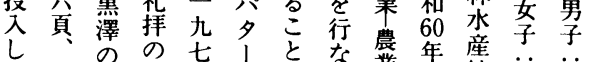

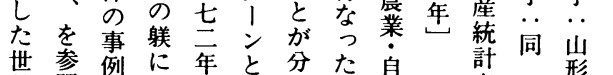

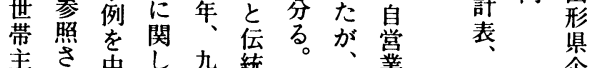

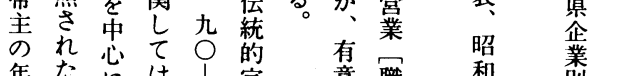

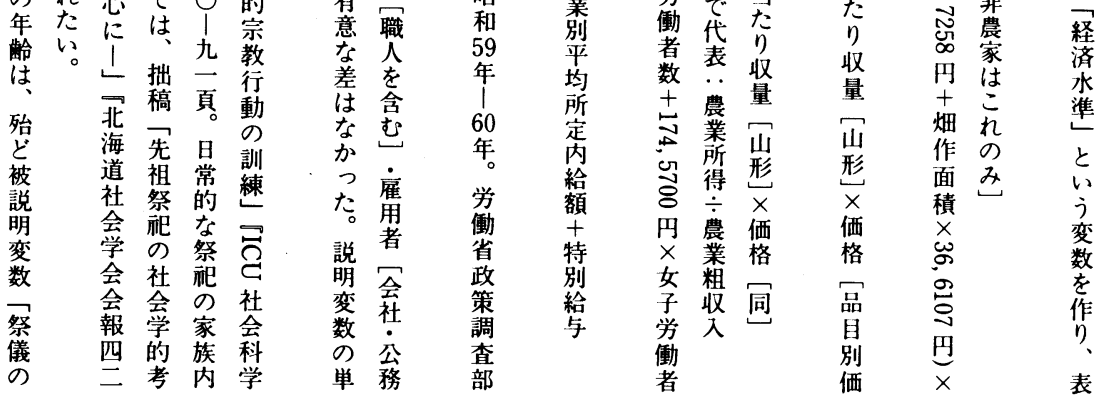

$39(2 \cdot 35) \quad 135$ 社会学評論 
がとにを婚家子じが先のい読けフの

第可同認通の獲たら崇関うみるオ実本 二能しめし死創得と、洋係天と家、態稿

にででらて者設の言生でを逝れ長テ分は

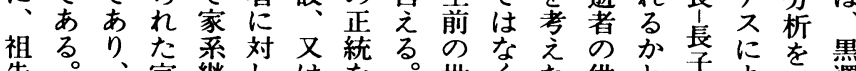

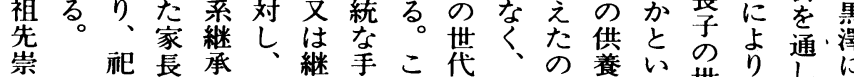
洋 る長者柤承段の間死でにう䒫提てお

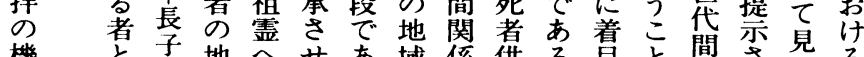
機 と子地芯せあ域係供る。目と間さ見る 能耏多位のるつに養。しで構れき祖

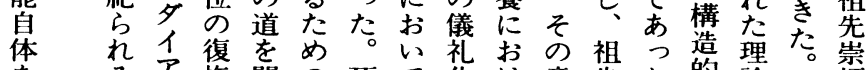

を、るア権開の死て、华け意先た的論そ拝

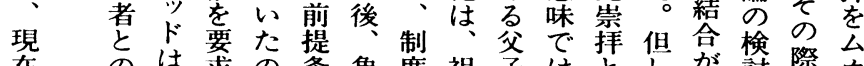

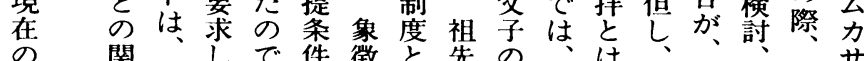
の 関祖たで件徴と先の構直逆本いす䦗节

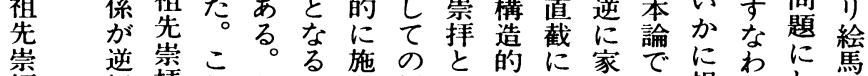
拝転拝れと子さ婚同結明長は祖ちし䏨 の しにらり孫れ姻じ合らの公先、た俗 実たお台わ㤈市か立力崇家のと 態もけ力け残婚复名あに場サ择交は現 分のるサ長さ姻家テるしかりの長、在

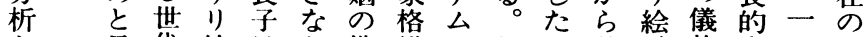
か 見代絵はか儀維のしの跡馬礼家つ祖 ら、る間馬、つ礼持中かは取習の族に先

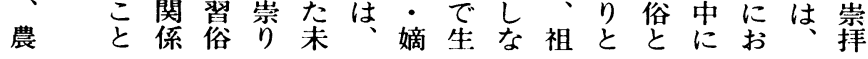

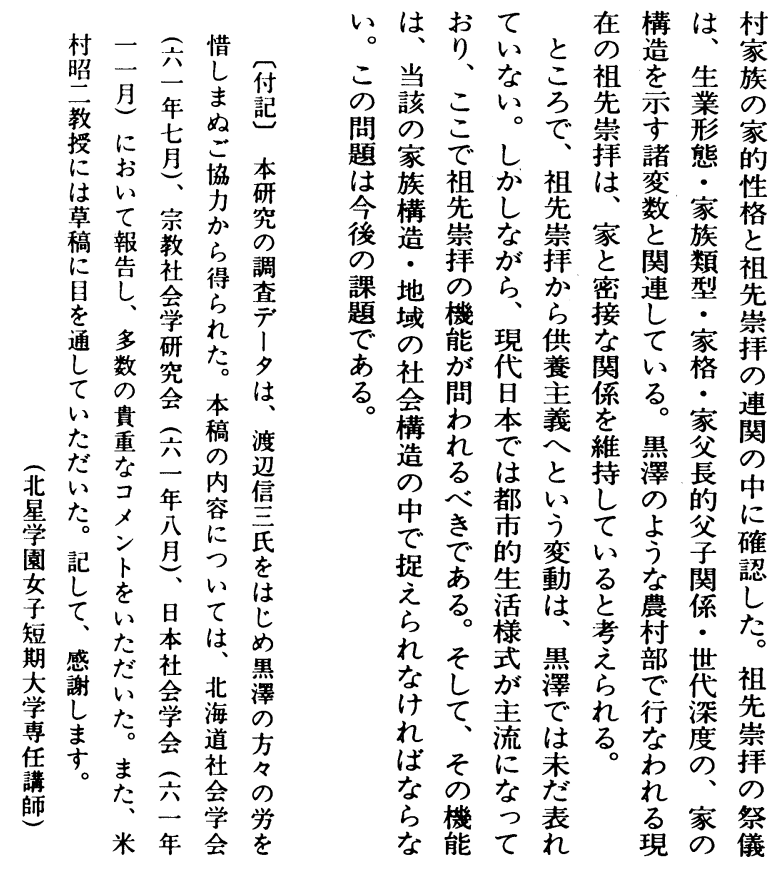




\title{
The Interactive Constitution of Action
}

\author{
Aug Nishizaka \\ Meiji Gakuin University
}

This paper will give an account as to how action is possible as an event. The fact that meaning of action is necessarily CONTINGENT forces us into reconceptualizing RULE (1). After overlooking speech-act theory, according to which MEANING of action is $<$ force $>$ as distinct from < sense $>$ of word (2), then, to meet its difficulty, the levels of speech act and of action as an event with a certain force will be differenciated. As for the latter, how it occurs will be considered by reference to <conversation analysis>, whose methode was systematically established by H. Sacks and his colleagues (3). In the last analysis, three rules will be given : < turn-taking system $>$ at the most basic level : < adjacency pairs $>$ and constitutive rules for speech act at the middle level. Action is constituted by the parties themselves managing interactively the process of the constitution, EXPLOITING the rules.

\section{Ancestor Worship and Family Structure in a Rural Community}

\author{
Yoshihide Sakurai \\ Hokusei Junior College
}

This paper studies the theory of ancestor worship suggested by M. Fortes et al. According to him, ancestor worship is the ritualization of filial piety which compels sons to accept fathers' jural authority, metamorphosing it into ancestors' mystical authority. Ancestor Worship is inextricably tied to the patriarchal family structure. This discussion will center on two points : 1) the interdependence of successive generations (fathers and their eldest sons) in the rites for the dead ; 2) the correlation between ancestral rites and agrarian family structure.

The data is from Kurosawa, a village in Yamagata Prefecture. This analysis reveals the following things :

1) The temple Choushuji has a folk ritual in which the pictorial votive offerings of marriage are given for the unmarried dead children. If these are not given, it is believed, one who does not have any legitimate successor cannot attain ancestorhood and will become a ghost muen-hotoke. The research of genealogical relations between the dead and the dedicator, indicates that eldest sons were dedicated by their fathers, while siblings by their mothers or elder siblings. This reveals the mutual dependence between a father and his eldest son, which goes with the fact that today, as in the past, an eldest son exclusively has a preeminent right of inheritance, especially due to his status as a household head and a citizen of the village. 
2) In contemporary Kurosawa, the rites of ancestor worship are practiced more frequently in agrarian families than in wage-earning ones ; in stem families than in conjugal ones ; in a household of higher rank than in a one of lower. And the greater the number of generations in a household's history, or the more a household retains a patriarchal filiation, the more ancestral rites are practiced.

In short, it is validated in quantitative analysis that ancestor worship still closely related to some of the characteristics of patrilineal family structure.

\title{
The Problem of Social Order Reconsidered
}

\author{
-T. Parsons and N. Luhmann-
}

\section{Koichi Tanaka \\ Shibaura Institute of Technology}

In this paper, we attempt to examine the solution to the social order problem proposed by Talcott Parsons from the standpoint set down by Niklas Luhmann; and to clarify the contribution of Luhmann's "theory of self-referential systems" to theoretical development in this area of sociology.

According to Parsons' theory of action, the concept of "system" has two meanings : (a) a system made up of actions, (b) a system made up of analytical elements (a system of action). Parsons does not discuss in detail the problem of social order in (a). Rather, he quickly shifts his discussion to another emergent level of system (b), as he considers the problem of social order to be reducible to that of how the norm-conforming action is motivated and accomplished.

We consider it essential that a more direct inquiry be made into the constitutional relation between a system and actions (elements), which Luhmann terms "the problem of self-reference". We describe, in terms of Luhmann's theory, "the mechanism of de-tautologization of self-reference", by means of which every concrete system and action is organized : a restriction of relations between actions, that is, building a normative structure.

Structure-building does not, however, necessarily result in the acceptance of a restriction determined by a normative structure. . Rather, it provides an actor with the alternatives of acceptance or rejection-in other words, with two possible responses to the structural restriction, with the structured complexity. Given a structure, one can act in response to other actions (other's actions) and recursively produce a succession of new actions. In conclusion, therefore, we define the social order as none other than the autopoietic reproduction of actions. 